\title{
(Mis)Allocation Effects of an Overpaid Public Sector*
}

\author{
Tiago Cavalcanti \\ University of Cambridge and Insper \\ tvdvc2@cam.ac.uk
}

\author{
Marcelo Rodrigues dos Santos \\ Insper \\ marcelors2@insper.edu.br
}

\begin{abstract}
In an economy in which the public sector is productive and factor inputs are rewarded according to their marginal productivity in both the public and the private sectors, the presence of a large government does not generate necessarily any allocation problem. When the provision of public infrastructure is below its optimal scale, then an increase in the size of the government can lead to an increase in total factor productivity (TFP). There is, however, a large body of evidence showing that for many countries the structure of wages and pensions and the labor law legislation are different for public and private employees. Such differences affect the occupational decision of agents and might generate some type of misallocation in the economy. We develop an equilibrium model with endogenous occupational choice, heterogeneous agents and imperfect enforcement to study the implications of an overpaid public sector. The model is estimated to be consistent with micro and macro evidence for Brazil and our counterfactual exercises show that public-private earnings premium can generate important allocation effects and sizeable productivity losses.
\end{abstract}

Keywords: Public-Private earnings premium; misallocation; and development. J.E.L. codes: E6; H3; J2; O1.

* We have benefited from discussions and conversations with Pedro Amaral, Tiago Berriel, Marco Bonomo, Guilherme Carmona, Francesco Caselli, Antonio Ciccone, Zhigang Feng, Jeremy Greenwood, Bernardo Guimarães, Hugo Hopenhaym, Tim Lee, Stephen Parente, José Víctor Ríos-Rull, Cézar Santos, Michèle Tertilt, Anne Villamil, Eduardo Zilberman and seminar participants at Birkbeck College, EESP-Vargas Foundation, INSPER, University of Illinois, University of Mannheim, and University of Konstanz. All remaining errors are ours. 
"Programmers and media industry workers had the highest percentage of self-identified diaosi, but only fewer than 10 percent of civil servants self-identified as diaosi." Tea Leaf Nation, June 2013. ${ }^{1}$

"There are many ways of striking it rich in Brazil, but one strategy may come as a particular surprise in today's economic climate: securing a government job." The New York Times, February 2013. ${ }^{2}$

"Shaadi.com reported a 30 per cent shift away from IT grooms towards other industries, particularly civil servants and managers at state-owned companies who have higher job security and recently were awarded a large pay rise by the government... Top of the scale are civil servants, those from the ultra-elite Indian Administrative Service and Indian Police Service." Financial Times, April 2009. ${ }^{3}$

\section{Introduction}

As the anecdotal evidence above (as well as the empirical facts provided in Section 2) suggests a career in the civil service seems to be an attractive profession for many individuals in different societies. Such a career might be associated with a good pay, job stability, and in supplying essential goods and services, such as the rule of law and public infrastructure, for the functioning of any society with direct influence not only in economic outcomes but also in the quality of life of individuals. In many countries a large proportion of the labor force works in the public sector and a large share of output is produced by the government. The OECD (2011) report, Government at a Glance, shows that there are also important cross-country differences on the share of the labor force working for government entities, organizations and corporations and on the size of the government. For instance, in 2008 governments in Norway

\footnotetext{
${ }^{1}$ Diaosi is a Chinese expression to describe a poor, young and unattractive person in China who cannot afford to buy a house and is unlikely to marry. The Economist (2014) has also feature a piece on the topic showing that Chinese workers who least identified themselves as Dioasi were civil servants.

${ }^{2}$ This piece of the The New York Times (2013) shows anecdotal evidence on how several public employees have exceeded constitutional limits on their pay, which is roughly US $\$ 13,000.00$. For instance, a clerk at a court in Brazil's capital, Brasília, was making more than the chief justice of the nation's Supreme Court. Other examples are of an auditor in Minas Gerais state who earned US $\$ 81,000$ in one month and a librarian who got US $\$ 24,000$ per month.

${ }^{3}$ In this report, the Financial Times (2009) shows that in the marriage market in India public servant grooms are the most demanded, and this is explained by their relative high income and job stability.
} 
and Denmark employed about 30 percent of the labor force, while in Korea only 5.7 percent of the labor force was employed in the public sector.

In an economy in which the public sector is productive and factor inputs are paid according to their marginal productivity in both the public and the private sectors, the presence of a large government does not generate necessarily any allocation problem. A larger government can on the contrary increase total factor productivity (TFP) if the provision of public infrastructure is below the optimal scale. There is, however, a large body of evidence showing that for many countries the structure of wages and pensions and the labor law legislation are completely different for public and private employees. Section 2 summarizes the empirical evidence on the public-private institutional and earnings gap. In general, the evidence suggests that, controlling for individual characteristics, public employees are on average better paid, have a more protected job and higher pension than private workers. In a recent work, Depalo, Giordano, and Papapetrou (2013), for example, show that for ten euro area countries wages are on average higher for public than private workers and for some countries such as Greece, Ireland, Italy, Spain and Portugal there is a large fraction of the this public-private wage gap that is unexplained by workers' characteristics. For instance, the raw average wage gap between public and private employees is 43 (36) percent in Portugal (Spain) and about 1/2 (2/3) of this gap is not explained by differences in education, experience and other observable characteristics. Could differences in labor compensation (e.g. wages and pensions) and labor legislation (e.g. job security) between private and public workers affect individuals' occupational choice, investment and generate important loss in aggregate productivity of an economy? This paper addresses this question.

Differences in earnings, compensation and labor legislations between public and private workers affect the occupational decision of agents and consequently generate some type of misallocation in the economy. The public sector might attract high productive and risk averse agents looking for a more stable and higher paid job, creating a public sector job queue and crowding out private sector employment and entrepreneurship. This can lead to a negative effect on the average labor productivity of workers in the private sector and it can also decrease the mass and the quality of entrepreneurs. Therefore, countries might be able to increase their short-run and long-run (if human capital accumulation depends on occupational choices) productivity by decreasing the public earnings premium and by reforming their labor law 
legislations. This might be particularly important in countries with inefficient and oversized public sectors. ${ }^{4}$

In order to guide our assessment, we construct an equilibrium model with endogenous occupational choice, heterogeneous agents and imperfect enforcement. In particular, the model economy considered in this paper is populated by a large number of agents who live for a realistic number of periods and have preferences over consumption. At each period of time, agents choose whether to work in the public or private sectors or to be an entrepreneur, as in the Lucas (1978) "span of control" model. When born agents draw from an invariant distribution two types of abilities: An ability to run a business and a labor market productivity. These two abilities evolve over time depending on the agents' occupational choice in a learning-by-doing and on-the-job training manner.

We calibrate and estimate the model to be consistent with key micro and macro statistics of the Brazilian economy. ${ }^{5}$ Then we perform counterfactual exercises by changing the wage premium in the public sector and by reforming the social security system such that pensions of civil servants are similar to pensions of private workers in the country. ${ }^{6}$ In the same spirit of Mortensen and Pissarides (1994), we keep the share of public employees constant by increasing the probability of a successful public job application (or alternatively by decreasing the cost of applying for a public job). We show that a decrease in the public wage premium from 25 percent to 13 percent can produce a sizeable positive effect on long-run aggregate output (6-16 percent increase) without any significative decrease in public infrastructure. Pension reforms can have similar aggregate effects. There is labor reallocation and substantial increases in capital accumulation and labor productivity. We believe our results have

\footnotetext{
${ }^{4}$ In addition, since fiscal consolidation has recently become one of the main issues in the public policy debate in most developed countries, the pressure for governments to restructure wages and pensions has increased. This paper investigates quantitatively the misallocation effects of a generous civil servant compensation and the potential output effects of government reforms to change the pension and wage scheme of public employees.

${ }^{5} \mathrm{Brazil}$ is an interesting case since it has a large public-private earnings and compensation premium. See Section 2 below. There is plenty of anecdotal evidence on Brazil's overpaid public sector. See, for instance, the New York Times quote above. Financial Times (2014) has also recently featured a piece on Brazil's public sector: "Looking for a job where you barely have to turn up to work, get paid about 27 times the minimum wage and can retire early on the handsome pension benefits? If the answer is "Yes", why not try Brazil's Congress?" Brazil's government size as a share of income is similar to the OECD average (cf., OECD, 2011).

${ }^{6}$ We also change the idiosyncratic process of income in order to study aggregate effects of changes in the stability of public jobs.
} 
far reaching implications for policies in countries with a large and inefficient public sector. We also provide a distributive welfare analysis and try to understand the main important channels driving our results.

There are a number of theoretical reasons explaining why earnings differentials between the private and public sector exist. For instance, it might be the case that the bargaining power of public and private workers are different resulting in a wage differential between the two sectors. The difference in bargaining power by public and private workers might be explained by historical reasons, the type of job associated with public services and/or due to differences in some labor law legislations (e.g., job security, right to strike) between the two sectors. It is not our goal to investigate why such earnings differentials exist and why some legislations protect more public than private employees. We take these wedges in earnings and benefits from the data and calculate the effects of those on investment and the allocation of talents in the economy and therefore on productivity and income levels.

This article is related to a large literature which investigates the underlying causes of low economic development and productivity in some countries. Differences in development level across countries can be explained by differences in factor accumulation and in the efficiency in which these factors are used in production. The existing literature suggests that both factors accumulation and total factor productivity (TFP) play key role in explaining income levels across countries. ${ }^{7}$ Human capital and physical capital accumulation depend on the return of such investments, which in turn depend on incentives and government policies of a society. A standard neoclassical growth model would for instance show that a tax on capital income will decrease investment and long-run income levels (cf., Lucas, 1990). TFP, on the other hand, might vary for two main reasons: First, because countries can either use different technologies in the production of goods and services (cf., Parente and Prescott, 1994) or use similar technologies differently (cf., Acemoglu and Zilibotti, 2001); and secondly because countries do not allocate inputs efficiently. In this second case, factor inputs are misallocated and factor reallocation from less to more productive establishments or jobs could potentially increase output. Hsieh and Klenow (2009), in an influential study, show that there is greater dispersion of productivity in India and China than in the United States and factors reallocation could increase TFP in China by 30-50\% and in India by $40-60 \%$. Their goal is to measure the size of misallocation, but they,

\footnotetext{
${ }^{7}$ For a survey of this literature see Caselli (2005) and Hsieh and Klenow (2010).
} 
however, do not explain why it exists. See also Restuccia and Rogerson (2008).

The literature on misallocation is growing rapidly in recent years and economists have studied different causes of why inputs of production are not allocated in the most productive manner such that the marginal productivity of input factors are equalized across different firms. Some of the theories to explain such misallocation are based on credit market imperfections and frictions, ${ }^{8}$ taxes and regulations, ${ }^{9}$ trade policies, ${ }^{10}$ among others. ${ }^{11}$ Restuccia and Rogerson (2013) provide an overview of this literature. Our article differs from this existing literature in an important way as (to our knowledge) none of the articles study the misallocation effects of the publicprivate earnings and institutional gaps. ${ }^{12}$

Related to our work is Hsieh, Hurst, Jones, and Klenow (2013) who in the same spirit of this paper investigate the aggregate productivity gains in the United States that can be attributed to decreases in labor market discrimination towards AfricanAmericans and women. They show that 15 to 20 percent of growth in output per worker in the United States from 1960 to 2008 can be explained by the decrease in the racial and gender wage gaps. The focus and question of our work are different. ${ }^{13}$ Also close to our ideas is a recent contribution by Jaimovich and Rud (2014)

\footnotetext{
${ }^{8}$ See Amaral and Quintin (2010), Antunes, Cavalcanti, and Villamil (2008), Buera and Shin (2013), Erosa and Hidalgo-Cabrillana (2008), Midrigan and Xu (2013), among others.

${ }^{9}$ See, for instance, Antunes and Cavalcanti (2007), Guner, Ventura, and Yi (2008), and Restuccia and Rogerson (2008).

${ }^{10}$ See Melitz (2003).

${ }^{11}$ Caselli and Gennaioli (2013) study the misallocation effects of dynastic family business. Their main idea is that if the offspring of the family firm has no managerial talent, then dynastic management is a failure of meritocracy that reduces a firm's TFP. Song, Storesletten, and Zilibotti (2011) build a model about the Chinese economic transition in which state-owned firms have better access to outside finance than do privately owned firms, even though the latter are more productive. Chinese growth is therefore in part explained by factors reallocation from state-owned to private owned firms. David, Hopenhayn, and Venkateswaran (2014) study the role of information in misallocation.

${ }^{12}$ Hörner, Ngai, and Olivetti (2007) study the role of state enterprise in the rise of European unemployment since the late 1970s. Quadrini and Trigari (2007) investigate the role of the public sector on the volatility of employment and output in a match model of the labor market. Related to this, Gomes (2014) in a matching environment studies the role of public sector wage policies in shaping unemployment levels, dynamics and business cycle fluctuations.

${ }^{13}$ Our environment is dynamic and we consider an entrepreneurial sector with credit frictions. Our article is also related to Glomm, Jung, and Tran (2009) who assess the effects of the Brazilian generous public sector pensions on capital accumulation and long-run income levels. We differ from them in several dimensions. First, we focus not only on pensions, but we also consider the effects of the public-private wage gap and other institutional differences between the two sectors. Our model is also different from theirs. We have endogenous occupational choice (e.g. civil servant, worker and entrepreneur) while they do not and therefore we are able to capture not only the effects of the publicprivate earnings gap on investment but also on extensive occupational margin and resulting misal-
} 
who study the effects of an oversized and inefficient public sector on economic performance through an endogenous occupational choice model. Their analysis is qualitative while ours is quantitative. They show, for instance, that when the public sector attracts bureaucrats with low degree of public service motivation, they will use their position to rent seek by employing an excessive number of unskilled workers and leading to an equilibrium with relatively high unskilled wages, which decreases profits and entrepreneurship. Given the focus of their question and in order to have an analytical solution, they have to simplify their analysis by for instance considering a static model and assuming exogenous levels of skills (skilled and unskilled). Our goal is to assess quantitatively the implications of earnings differentials in public and private sectors and therefore we assume endogenous skill formation and a dynamic environment.

The remainder of the paper is organized as follows. The data facts are presented in Section 2. Section 4 presents the model economy. Section 5 calibrates and estimates model parameters and provides the quantitative analysis to measure the aggregate effects of public-private earnings and institutional gap. Section 6 contains concluding remarks.

\section{Data Facts}

In this section we document main facts which motivate this study and provide empirical support to some of our modelling assumptions and counterfactual exercises. There are four facts which are summarized below.

Before stating the empirical facts related to our interest, we first observe that a large proportion of the labor force works in the public sector and there are important differences across countries. For instance, in 2008 governments in Scandinavian countries employed almost 30 percent of all workers. This number was 5.7 percent for Korea and about 8.6 percent in Brazil. ${ }^{14}$ The size of government and consequently the fraction of workers in the public sector vary for several reasons, such as the extension

location. Reis and Zilberman (2014) investigate the role of insurance in public employment. They show that if the share of public employment decrease, overall welfare might decrease due to general equilibrium effects, but there are welfare losses coming from a lower degree of insurance.

${ }^{14}$ Data from the International Labour Organization shows that for 2010 about 10.3 percent of the labor force was working in the public sector in Brazil. Using the 2008 PNAD we also show that the share of individuals working in the public sector is roughly $10 \%$. See Appendix A. 
of the franchise to poorer individuals as argued in a seminal paper by Meltzer and Richard (1981), the openness of a country (cf., Rodrik, 1998), or the scope of the public sector (cf., Rosen, 1996). It is not our goal to discuss what should be the optimal scope of the government or the importance of the government in providing certain public goods and services. We will instead investigate whether or not differences in labor compensation between public and private workers can potentially generate important losses (or gains) in economic efficiency. This motivates the list of the three following factors below.

Fact 1: Public-private wage gap. In most countries there exists a public-private wage gap. In some of these countries a large fraction of this wage gap is not explained by differences in observed characteristics, such as education and experience. There is a large empirical literature documenting the unexplained wage gap between public and private employees for several countries. Recently, Depalo, Giordano, and Papapetrou (2013) studied the public-private wage gap for ten European countries. For some countries such as Portugal and Spain the raw average wage gap between public and private employees is 43 and 36 percent, respectively. In Portugal about half of this gap is not explained by differences in observable characteristics, while in Spain the unexplained public-private wage gap is about $2 / 3$ of the total raw wage gap. A similar pattern is observed in Turkey (cf., Tansel, 2005), Britain ${ }^{15}$ (Postel-Vinay and Turon, 2007, cf.,) and Brazil (cf., Belluzzo, Anuatti-Neto, and Pazello, 2005). See more evidence on Brazil in Appendix A. Interestingly, most of these studies show that the public-private wage gap decreases for the upper tail of the conditional wage distribution and there is less dispersion in income inequality in the public sector.

Fact 2: Public-private pension gap. Not only there exists a public-private wage gap but in some cases the pension system is also different between private sector and public sector workers. As described in a report from The Economist ${ }^{16}$ on July $27^{\text {th }}$ 2013, in America most public-sector workers can expect a pension linked to their final salary. This is not a common practice in the private sector in which only 20 percent of private-sector workers benefit from such a scheme. As The Economist points out when analysing the pension system in the United States, in general in America 'the

\footnotetext{
${ }^{15}$ For Britain, Postel-Vinay and Turon (2007) show that there exists for similar workers a positive average public premium both in income flows and in the present discounted sum of future income flows. They also find that income inequality is lower and more persistent in the public sector.

${ }^{16}$ See The Economist, July $27^{\text {th }}$, Who Pays the Bill?
} 
typical public-sector worker gets a pretty good deal by private-sector standards'. ${ }^{17}$ A similar pattern is also observed in Britain where pensions in the public sector are based on the final-salary (defined-benefit plan) and the pension of private sector workers rely on defined-contribution schemes, which is based on how much the employee and employer contributed and on the return of pension funds. ${ }^{18}$ Brazil also has a very unequal pension system, which is divided into two main schemes: a general regime for private sector workers and a special regime for civil servants (cf., Cunha, Ferreira, and dos Santos, 2012). The scheme available to private sector workers consists of a mandatory publicly managed transfer system which covers all private workers up to a ceiling of approximately US\$1,800. In the public sector, workers can retire with full salary if they are 65 years old and contributed to the pension system for 35 years. Tafner (2011) shows that government expenditures with retirees from the public sector correspond to about 36 percent of the total government expenditures with pension in Brazil, but such expenditures benefit only 7.5 percent of all retirees in the country. ${ }^{19}$

Fact 3: Public-private institutional gap. The OECD (2011) report shows that many countries have labor legislation which translates in more secured jobs in the public than in the private sector. Clark and Postel-Vinay (2009) construct indicators of the perception of job security for 12 European countries. They find that after controlling for selection into job types, workers feel most secure in permanent public sector jobs and such jobs are perceived to be by and large insulated from labor market fluctuations. He, Huang, Liu, and Zhu (2014) provide interesting indirect evidence on job security for China. Using a large-scale reform which decreased job stability in stateowned enterprises (SOEs) but not for government employees in China in the late 1990s, they show significant evidence of precautionary saving stemming from sudden increases in unemployment risk for SOE workers relative to that for government employees. In Brazil workers in the public sector are guaranteed life tenure after a three-year probation period and since there are no performance evaluation mecha-

\footnotetext{
${ }^{17}$ Beshears, Choi, Laibson, and Madrian (2011) describe the pension system of the states and the largest cities and counties in the US. Although, they report substantial heterogeneity across jurisdictions, they show that unlike in the private sector, defined-benefit pensions are still the norm in the public sector.

${ }^{18}$ Article by Queisser, Whitehouse, and Whiteford (2008) describes different features of the pension system in OECD countries.

${ }^{19}$ The government has changed this for the new public employees. Those who now get a public sector job will have to contribute more in order to receive the full pay under retirement. Current public sector workers still face the previous pension scheme.
} 
nisms in the public sector, rarely an employee is not awarded tenure in the public sector. Consequently, tenure in private sector is skewed to the left while in the public sector it is more uniformly distributed.

In the remaining of this article, we will investigate whether or not these institutional and earnings gaps generate misallocation and productivity losses in the economy. The economic environment to discipline our analysis is described below.

\section{Static Model Intuition}

First we present a simplified version of the model to provide some key intuition. The full model is introduced in Section 4. For analytical tractability, we consider a static occupational model without capital and close to the environment described by Lucas (1978). The economy is inhabited by a continuum of individuals of measure one who live for only one period. Each Individual is endowed with one unit of labor and with entrepreneurial ability $h_{e}$, which corresponds to her capacity to employ labor, $n$, in order to produce a single (private) consumption good, $y_{h_{e}}$. Productivity $h_{e}$ follows a log-normal distribution with location parameter $\mu_{e}$ and scale parameter $\sigma_{e}$. Let's represent this probability distribution of $h_{e}$ by $F_{e}\left(h_{e}\right)$. The entrepreneurial production technology is represented by

$$
y_{h_{e}}=G^{\chi} h_{e}^{1-v} n^{v(1-\varphi)}, v, \varphi \in(0,1), \chi \geq 0,
$$

where $v$ is the span-of-control parameter and $1-\varphi$ determines the importance of labor in production. $G$ is a public good. Following Barro (1990), G can be seen as the stock of public infrastructure such as toll free roads, which is made available to all firms at a zero price. The general idea of including $G$ as a separate argument in the production function is that labor $n$ is not a close substitute for public inputs. Entrepreneurs can operate only one establishment. Let $w$ denotes the wage rate. The problem of an entrepreneur with managerial ability $h_{e}$ is to choose labor, $n$, to maximize:

$$
\pi\left(h_{e} ; w\right)=\max _{n \geq 0} G^{\chi} h_{e}^{1-v} n^{v(1-\varphi)}-w n .
$$


This problem gives labor demand for each entrepreneur:

$$
n\left(h_{e} ; w\right)=\left(\frac{v(1-\varphi)}{w} G^{\chi}\right)^{\frac{1}{1-v(1-\varphi)}} h_{e}^{\frac{1-v}{1-v(1-\varphi)}} .
$$

Then we can also define optimal production and profits of each entrepreneur.

$$
\begin{aligned}
& y\left(h_{e} ; w\right)=\left[\left(\frac{v(1-\varphi)}{w}\right)^{v(1-\varphi)} G^{\chi}\right]^{\frac{1}{1-v(1-\varphi)}} h_{e}^{\frac{1-v}{1-v(1-\varphi)}}, \\
& \pi\left(h_{e} ; w\right)=(1-v(1-\varphi)) y\left(h_{e} ; w\right) .
\end{aligned}
$$

We assume that the public good is produced by the government. The public sector technology is given by:

$$
G=A_{g} N_{g}^{1-\alpha}, \alpha \in(0,1),
$$

where $A_{g}>0$ is a productivity factor.

Individuals choose a career in order to maximize income. An individual receives gross income $\pi\left(h_{e} ; w\right)$ if she becomes an entrepreneur and $w$ if she becomes a worker. They can also be a civil servant. We assume that the public sector wage $w^{g}$ and the size of the labor force employed in this sector are exogenously determined. We assume that there is a wage premium to work in the public sector, such that civil servants receive $w^{g}=(1+\zeta) w$, where $\zeta \geq 0$. The public sector is financed by a proportional tax, $\tau_{c}$, on consumption.

Let $c$ be consumption of an individual whose preferences are represented by a function $u(c)=\frac{c^{1-\gamma}}{1-\gamma}$ with $\gamma>0$. Individuals maximizes utility subject to the constraint that $\left(1+\tau_{c}\right) c \leq \tilde{y}$, where $\tilde{y}$ corresponds to the income of each household, which depends on the agent career choice.

Lemma 1. For each $w>0$ and $\zeta \geq 0$, there exists an entrepreneurial ability

$$
\bar{h}_{e}(w ; \zeta)=\left[\frac{(1+\zeta)^{1-v(1-\varphi)} w}{(v(1-\varphi))^{v(1-\varphi)}(1-v(1-\varphi))^{1-v(1-\varphi)}} \frac{1}{G^{\chi}}\right]^{\frac{1}{1-v}}>0,
$$

such that for all $h_{e} \geq \bar{h}_{e}(w ; \zeta)$, then $\pi\left(h_{e} ; w\right) \geq(1+\zeta) w$.

Proof. Use $\pi\left(h_{e} ; w\right) \equiv(1+\zeta) w$ to find $\bar{h}_{e}(w ; \zeta)$.

Q.E.D. 
Notice that $\bar{h}_{e}(w ; \zeta)$ is continuous and increasing in both $\zeta$ and $w$. This Lemma suggests that individuals with $h_{e} \geq \bar{h}_{e}(w ; \zeta)$ will choose to become entrepreneurs. In addition, there exists a productivity level $\bar{h}_{w}(w)$ defined by

$$
0<\bar{h}_{w}(w)=\frac{\bar{h}_{e}(w ; \zeta)}{(1+\zeta)^{1-v(1-\varphi)}} \leq \bar{h}_{e}(w ; \zeta)
$$

which is independent of $\zeta$ and is continuous and increasing in $w$, such that for all $h_{e} \leq \bar{h}_{w}(w)$, then $\pi\left(h_{e} ; w\right) \leq w$. Individuals with entrepreneurial productivity $h_{e} \leq$ $\bar{h}_{w}(w)$ will not choose to be entrepreneurs.

In order to define who become civil servants notice the following. All individuals with $h_{e}<\bar{h}_{e}(w ; \zeta)$ would like to work in the public sector. But assume that only a fraction $\phi_{g} \in(0,1)$ can become a public employee. Assume that this is determined exogenously in the model. There are several possible cases in which we could select civil servants, but consider two polar examples: (i) in the first case, only individuals with productivity $h_{e} \in\left[0, \bar{h}_{g}\right]$ become civil servants, such that $F_{e}\left(\bar{h}_{g}\right)=\phi_{g}$. Then, in order to have production of goods in equilibrium, it must be the case that $\bar{h}_{g}<$ $\bar{h}_{w}(w)$. Consequently, all individuals with $h_{e} \geq \bar{h}_{w}(w)$ are entrepreneurs, ${ }^{20}$ while private sector workers are those individuals with entrepreneurial productivity $h_{e} \in$ $\left[h_{g}, \bar{h}_{w}(w)\right]$. In this case, both $\bar{h}_{g}$ and $\bar{h}_{w}(w)$ are independent of $\zeta$. Then changes in the public sector wage premium, $\zeta$, would not affect occupational choice, labor demand and therefore aggregate output in equilibrium. ${ }^{21}$ A second more interesting case is the one that public employees are defined by individuals with $h_{e} \in\left[\bar{h}_{g}, \bar{h}_{e}(w ; \zeta)\right)$, such that $F_{e}\left(\bar{h}_{e}(w ; \zeta)\right)-F_{e}\left(\bar{h}_{g}\right)=\phi_{g}$. Since $\phi_{g}$ is held constant, it implies that $\bar{h}_{g}(w ; \zeta)$ will be a continuous and increasing function of $w$ and $\zeta$. Figure 1 presents a line which describes the occupational choice for this example, which varies with the size of the public sector. In the left graph, the size of the public sector is not too large and this implies that $\bar{h}_{g}(w ; \zeta)>\bar{h}_{w}(w)$, while the right graph shows the case in which $\bar{h}_{g}(w ; \zeta)<\bar{h}_{w}(w)$.

In equilibrium the labor excess demand, $\operatorname{LED}(w ; \zeta)$, is:

$$
L E D=\int_{\bar{h}_{e}(w ; \zeta)}^{\infty} n\left(h_{e} ; w\right) d F_{e}\left(h_{e}\right)+\int_{\bar{h}_{w}(w)}^{\max \left\{\bar{h}_{g}(w ; \zeta), \bar{h}_{w}(w)\right\}} n\left(h_{e} ; w\right) d F_{e}\left(h_{e}\right)-\int_{0}^{\min \left\{\bar{h}_{g}(w ; \zeta), \bar{h}_{w}(w)\right\}} d F_{e}\left(h_{e}\right)
$$

\footnotetext{
${ }^{20}$ Some individuals who become entrepreneurs would like to work in the public sector, i.e., those with $h_{e} \in\left[\bar{h}_{w}(w), \bar{h}_{e}(w ; \zeta)\right]$.

${ }^{21}$ The tax rate $\tau_{c}$ will adjust with $\zeta$ and therefore welfare will change with $\zeta$, but aggregate output remains unchanged for a given share of public sector workers $\phi_{g}$.
} 

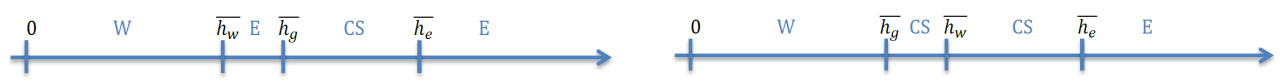

Figure 1: Occupational choice. Left graph: Not too large public sector and employee selection in this sector depends positively on $h_{e}$. Right graph: Large public sector and employee selection in this sector depends positively on $h_{e}$.

and the following result can be demonstrated.

Proposition 1. Let public employees be those individuals with entrepreneurial productivity $h_{e} \in\left[\bar{h}_{g}(w ; \zeta), \bar{h}_{e}(w ; \zeta)\right]$ with $\bar{h}_{g}(w ; \zeta)>0$ and assume that the government keeps the share of public employees constant. Then there exists a unique wage rate $w(\zeta)$, which clear the labor market. In addition, $w(\zeta)$ is decreasing in $\zeta$.

Proof. The labor demand function $n\left(h_{e} ; w\right)$ is continuous in $w$ and since productivity levels $\bar{h}_{e}(w ; \zeta)$, and $\bar{h}_{w}(w)$ vary smoothly with $w$, then the labor excess demand function $\operatorname{LED}(w ; \zeta)$ is also continuous in $w$. In addition, $n\left(h_{e} ; w\right)$ is strictly decreasing in $w$, while $\bar{h}_{e}(w ; \zeta)$ and $\bar{h}_{w}(w)$ are strictly increasing in $w,{ }^{22}$ which imply that $L E D(w ; \zeta)$ is strictly decreasing in $w$. As $w \rightarrow 0$, then $\bar{h}_{e}(w ; \zeta)$ and $\bar{h}_{w}(w)$ go to zero and no agent wishes to become a worker. It follows that $\operatorname{LED}(w ; \zeta)>0$. When $w$ increases sufficiently, $\operatorname{LED}(w ; \zeta)<0$, since all agents wish to become workers (or civil servants). Therefore, by continuity of $\operatorname{LED}(w ; \zeta)$, there must be an unique $0<w(\zeta)<\infty$ such that $\operatorname{LED}(w(\zeta) ; \zeta)=0$. In addition, using the implicit function theorem it can be shown that $w^{\prime}(\zeta)<0$.

Q.E.D.

The last part of Proposition 1 suggests that the wage rate decreases with a higher public sector wage premium. The reason is that a higher wage premium $\zeta$ increases the threshold productivity $\bar{h}_{e}(w ; \zeta)$ and this decreases the demand for labor for a given wage rate. When $\bar{h}_{g}(w ; \zeta)<\bar{h}_{w}(w)$ and the government keeps the share of public employees constant, then an increase in the public sector wage premium increases labor supply and decreases the share of entrepreneurs in the economy. These two effects lead to a fall in the equilibrium wage rate. When $\bar{h}_{g}(w ; \zeta)>\bar{h}_{w}(w)$, then an increase in $\zeta$ decreases the share of entrepreneurs with ability higher that $\bar{h}_{e}(w ; \zeta)$, but increases by the same proportion the share of entrepreneurs with $h_{e} \in$ $\left[\bar{h}_{w}(w), \bar{h}_{g}(w ; \zeta)\right]$. However, since labor demand varies positively with ability $h_{e}$, we

\footnotetext{
${ }^{22}$ If the government keeps the number of public employees constant such that $F_{e}\left(\bar{h}_{e}(w ; \zeta)\right)-$ $F_{e}\left(\bar{h}_{g}(w ; \zeta)\right)=\phi_{g}$, then $\bar{h}_{g}(w ; \zeta)$ will also vary smoothly with $w$ and it will be increasing with $w$.
} 
have that total labor demand for a given wage decreases. The supply of labor remains constant. Therefore, the wage rate also falls.

Aggregate output for this economy is represented by:

$$
Y=\int_{\bar{h}_{e}(w ; \zeta)}^{\infty} y\left(h_{e} ; w\right) d F_{e}\left(h_{e}\right)+\int_{\bar{h}_{w}(w)}^{\max \left\{\bar{h}_{g}, \bar{h}_{w}(w)\right\}} y\left(h_{e} ; w\right) d F_{e}\left(h_{e}\right)
$$

Using (4) into the above equation implies that

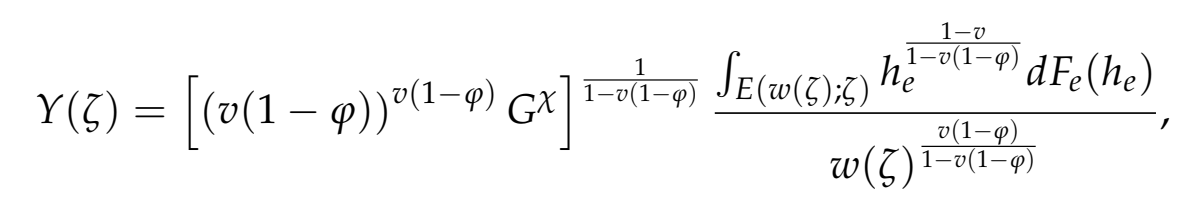

where $E(w(\zeta) ; \zeta)$ corresponds to the measure of individuals who are entrepreneurs and $G=A_{g} \phi_{g}^{\alpha}$. Notice that this equation implies that

$$
Y(\zeta)=\bar{A}(\zeta)=\propto \frac{\int_{E(w(\zeta) ; \zeta)} h_{e}^{\frac{1-v}{1-v(1-\varphi)}} d F_{e}\left(h_{e}\right)}{w(\zeta)^{\frac{v(1-\varphi)}{1-v(1-\varphi)}}}
$$

There are two opposing effects on productivity of an increase in the public sector wage premium when the government keeps the share of public employees constant. The first one is a selection effect. Either the share of entrepreneurs decreases (when $\left.\bar{h}(w ; \zeta)<\bar{h}_{w}(w)\right)$ or the quality of entrepreneurs decreases (when $\bar{h}_{g}(w ; \zeta)>\bar{h}_{w}(w)$ ) and therefore in both cases aggregate productivity decreases. A second effect comes from the general equilibrium nature of our model. An increase in $\zeta$ decreases the wage rate and therefore makes labor cheaper and output for each entrepreneur rises. Consequently, the overall effect of an increase in the public wage premium on output is ambiguous. It is important to emphasize that in our analysis the size of the government and the production of public infrastructure are kept constant since the share of public employees is constant and all individuals have the same productivity as workers.

An extension of this simple framework is to introduce heterogeneity in labor productivity. For instance, in addition to entrepreneurial productivity $h_{e}$, assume that each worker is also characterized by an idiosyncratic labor productivity $h_{w}$, drawn from a $\log$-normal distribution with location parameter $\mu_{w}$ and scale parameter $\sigma_{w}$. 
Therefore, agents are heterogenous in the pair $\left(h_{e}, h_{w}\right)$. Then the following Lemma can be established.

Lemma 2. For each $w>0, \zeta \geq 0$, and $h_{w}>0$ there exists an entrepreneurial ability

$$
\bar{h}_{e}\left(h_{w}, w ; \zeta\right)=\left[\frac{(1+\zeta)^{1-v(1-\varphi)} w h_{w}^{1-v(1-\varphi)}}{(v(1-\varphi))^{v(1-\varphi)}(1-v(1-\varphi))^{1-v(1-\varphi)}} \frac{1}{G^{\chi}}\right]^{\frac{1}{1-v}}>0,
$$

such that for all $h_{e} \geq \bar{h}_{e}\left(h_{w}, w ; \zeta\right)$, then $\pi\left(h_{e} ; w\right) \geq(1+\zeta) w h_{w}$.

Analogously, for each $h_{w}$, we can define the line

$$
0<\bar{h}_{w}\left(h_{w}, w\right)=\frac{\bar{h}_{e}\left(h_{w}, w ; \zeta\right)}{(1+\zeta)^{1-v(1-\varphi)}} \leq \bar{h}_{e}\left(h_{w}, w ; \zeta\right)
$$

which is independent of $\zeta$ and is continuous and increasing in $w$, such that for all $h_{e} \leq$ $\bar{h}_{w}\left(h_{w}, w\right)$, then $\pi\left(h_{e} ; w\right) \leq w h_{w}$ and individuals with productivity $h_{e} \leq \bar{h}_{w}\left(h_{w}, w\right)$ will not choose to be entrepreneurs.

The area above line $\bar{h}_{e}\left(h_{w}, w ; \zeta\right)$ is represented by the dark grey shaded area in Figure 2. Individuals with the combination of $\left(h_{e}, h_{w}\right)$ that lies above $\bar{h}_{e}\left(h_{w}, w ; \zeta\right)$ become entrepreneurs. Individuals whose productivity pair $\left(h_{e}, h_{w}\right)$ lies below line $\bar{h}_{e}\left(h_{w}, w ; \zeta\right)$ would like to become civil servants. However, due to job rationing in the public sector not all individuals become civil servant. There are several possibilities. Figure 2 presents two cases. The left graph of Figure 2 shows the case in which selection in public sector jobs depends positively on both labor and entrepreneurial productivity, while the graph on the right presents the case in which selection for public employees are entirely based on productivity as workers. Observe that some individuals with productivity below $\bar{h}_{e}\left(h_{w}, w ; \zeta\right)$ but above $\bar{h}_{w}\left(h_{w}, w\right)$ might become entrepreneurs.

Now, it becomes harder to derive analytical implications of the model. One of the reasons is that when the wage premium in the public sector is modified, not only there will be changes in the share of entrepreneurs as before, but even when the government keeps the share of the labor force constant in the public sector, public infrastructure might also change due to the selection effect on public sector jobs. We can still show that there exists a unique wage which clears the market and that it decreases with the wage premium in the public sector. This simple framework is based 

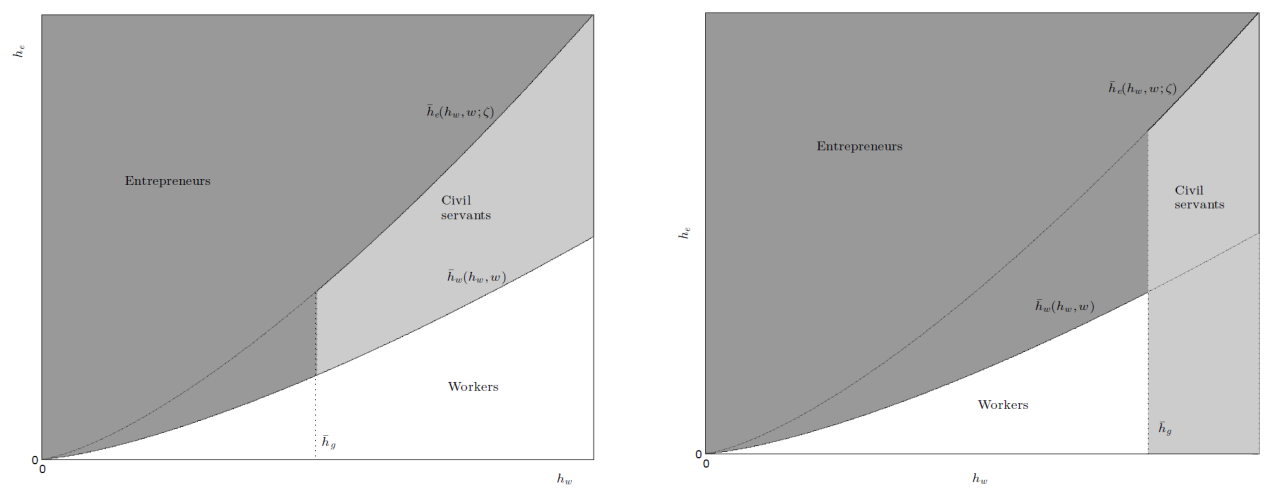

Figure 2: Occupational choice. Left graph: Selection in the public sector depends positively on $h_{w}$ and $h_{e}$. Right graph: Selection in the public sector depends (positively) only on $h_{w}$.

on a static model in which the decision to work in the public sector is exogenous and the pair of productivity $\left(h_{e}, h_{w}\right)$ does not evolve over time. In addition, there is no wealth dynamics, capital in production and credit market frictions, which can also affect occupational choices. Although this provides a useful device to understand the mechanism of how an overpaid public sector might affect productivity, it is certainly a limited environment for quantitative analysis. We therefore present next the full model in which we base our quantitative results.

\section{The Environment}

\subsection{Demography, preferences and Career choices}

Time is discrete and the economy has an infinite horizon. The economy is populated by a continuum of individuals of mass one. In each time period, a new generation is born with probability one. These individuals survive for a finite number of periods $T$, which is deterministic. The age profile of the population is given by $\left\{\mu_{t}\right\}_{t=1}^{T}$, where $\mu_{t}$ is the share of age- $t$ agents in the economy and satisfies $\sum_{t=1}^{T} \mu_{t}=1$. In order to simplify notation we omit the time subscript.

They derive utility from consumption, $c_{t}$, and when not retired individuals are endowed with one unit of time in each period. Preferences over random paths for 
consumption over the life cycle are represented by:

$$
E_{t=1}\left[\sum_{t=1}^{T} \beta^{t-1} u\left(c_{t}\right)\right],
$$

where $\beta$ is the subjective discount factor, and $E$ is the expectations operator conditional on information at birth. The period utility is assumed to take the form of a power utility function:

$$
u\left(c_{t}\right)=\frac{c_{t}^{1-\gamma}}{1-\gamma},
$$

where $\gamma$ denotes the risk aversion parameter or the inverse of the intertemporal elasticity of substitution.

In each period, agents decide whether to run an entrepreneurial activity, $e$, or to supply their time endowment to the labor market. In the latter case, they can choose to work either in the private sector, $w k$, or as a civil servant, cs. At a certain age $T_{r}$, agents retire and receive social security payments at an exogenously specified replacement rate of current average wages. The social security regime in the public sector is different from the one in the private sector. We capture this feature by allowing the replacement rate to differ under the two regimes. Let $d_{m, t}$ for $m \in\{c s, w k, e, r g, r p\}$ denote an individual's occupation, where $d_{r g, t}$ denotes and individual who retired from the public sector and $d_{r p, t}$ denotes an individual who retired from the private sector. These occupational statuses are mutually exclusive, which means that, for instance, if $d_{c s, t}=1$ then $d_{m, t}=0$ for all $m \neq c s$.

\subsection{Private sector technology}

There are two sectors of production. Following Quadrini (2000), the first sector (Noncorporate Sector) is characterized by small units of production (small firms), where each business activity is related to one specific manager. ${ }^{23}$ Households engage in entrepreneurial activities in this sector. The second (Corporate sector) one is dominated by large impersonality units of production (large firms). The main features that differentiate a small business from a big corporation are the uninsurable entrepreneurial risk and the strictness of the financial constraints. The Corporate sector does not face the same incentive problems and risks of the sector intensive in management skills

\footnotetext{
${ }^{23}$ See also Wynne (2005).
} 
and its presence is important for the quantitative analysis since in the data not all production is generated by business activities associated to one household.

Noncorporate sector. Total production in the noncorporate sector is generated by the aggregation of all production technologies run by households engaging in entrepreneurial activities. Each technology comprises a manager with entrepreneurial ability, $h_{e}$, which corresponds to her capacity to employ labor, $n$, and capital, $k$, to produce a single (private) consumption good, $y_{h_{e}}$. Subsection 4.4 describes how $h_{e}$ evolves over time. The entrepreneurial production technology is represented by

$$
y_{h_{e}}=z G^{\chi} h_{e}^{1-v} f(k, n)^{v}=z G^{\chi} h_{e}^{1-v}\left(k^{\varphi} n^{1-\varphi}\right)^{v}, v, \varphi \in(0,1), \chi \geq 0 .
$$

Variable $z$ is a random shock and captures an idiosyncratic business risk. We assume a very parsimonious representation for $z$, such that in every period with probability $\Delta$, the same technology is available for the entrepreneur and $z=1$. However, with probability $1-\Delta, z=0$, there is no production and the individual becomes a worker. Production takes place after the realization of $z$.

Managers can operate only one establishment. Let $w$ denotes the wage rate. The problem of an entrepreneur aged $t$ with managerial ability $h_{e, t}$ and capital stock $k_{t}$ is to choose labor, $n_{t}$, to maximize: ${ }^{24}$

$$
\pi_{t}\left(h_{e, t} ; k_{t}\right)=\max _{n_{t} \geq 0} G^{\chi} h_{e, t}^{1-v} f\left(k_{t}, n_{t}\right)^{v}-w n_{t}
$$

The choice of capital input is a bit more complicated, since capital has to be paid in advance and there is a commitment problem. Entrepreneurs can finance their business by using their net wealth or by borrowing from financial intermediaries. Denote by $a_{t}$ an agent's wealth and by $r$ the endogenous interest rate. Individuals have access to competitive financial intermediaries, who receive deposits and rent capital $k$ at rate $R$ to entrepreneurs. The zero-profit condition of the intermediaries implies $R=r+\delta$, where $r$ is the deposit and lending rate and $\delta$ is the depreciation rate. Borrowing by entrepreneurs is limited by imperfect enforceability of contracts. We assume that, after production has taken place, entrepreneurs may renege on the financial contract. In

\footnotetext{
${ }^{24}$ Variable $z$ is realized before production takes place. Therefore, it does not appear in the static problem of the entrepreneur because implicitly we are assuming that when there is production then $z=1$, and in the case in which $z=0$ there is no production.
} 
such case, entrepreneurs can keep fraction $1-\phi$ of the underpreciated capital and the revenue net of labor payments, but they lose their financial assets deposited with the financial intermediary, $a_{t}$. Thus, the entrepreneurs' incentive compatibility constraint can be written as follows:

$$
\pi_{t}\left(h_{e, t} ; k_{t}\right)-R k_{t} \geq(1-\phi)\left[\pi_{t}\left(h_{e, t} ; k_{t}\right)+(1-\delta) k_{t}\right]-(1+r) a_{t}
$$

The incentive compatible constraint (17) guarantees that ex-ante repayment promises are honoured, such that there is no default in equilibrium. Given factor prices $w$ and $R$, final profits of an entrepreneur aged $t$ is given by:

$$
\Pi_{t}\left(a_{t}, h_{e, t}\right)=\max _{k_{t} \geq 0} \pi_{t}\left(h_{e, t} ; k_{t}\right)-R k_{t}
$$

subject to (17).

Corporate sector. Firms in the corporate sector produce the consumption good through a standard constant returns to scale production function:

$$
Y_{c}=G^{\chi} K_{c}^{\alpha} N_{c}^{1-\alpha}, \alpha \in(0,1)
$$

Corporate firms do not face the same financial restrictions as firms in the entrepreneurial sector because large corporate organizations are not subject to the same enforcement and incentive restrictions. This implies that corporate firms can borrow from banks at the equilibrium interest rate or alternatively they can issue bonds at the equilibrium interest rate. They take prices as given and choose factors of production to maximize profits. The first-order conditions of a representative corporate firm are given by:

$$
\begin{gathered}
r=\alpha G^{\chi}\left(\frac{K_{c}}{N_{c}}\right)^{\alpha-1}-\delta, \\
w=(1-\alpha) G^{\chi}\left(\frac{K_{c}}{N_{c}}\right)^{\alpha} .
\end{gathered}
$$

\subsection{Government sector}

We assume that the public good is produced by the government. The public good, $G$, is produced using efficient labor units $N_{g}$ and capital $K_{g}$ according to the following 
technology:

$$
G=A_{g} K_{g}^{\alpha} N_{g}^{1-\alpha}, A_{g}>0 .
$$

Public sector capital evolves according to the following law of motion:

$$
K_{g, t+1}=I_{g}+\left(1-\delta_{g}\right) K_{g, t}
$$

where public investment $I_{g}$ is financed through taxes.

There are two different social security regimes: A scheme for private workers and entrepreneurs and a scheme for public workers. The replacement rate for civil servants is different from the one faced by private sector workers. This is consistent with Fact 2 in Section 2. Consequently, in the model we have two types of retirees: individuals who retired from the public sector and individuals who retired from the private sector.

In addition, we assume that the government carries out an exogenous flow of expenditure, $C_{g}$, which includes other parts of government consumption such as military expenditure that is deemed to be unproductive in our model. As we show later, $C_{g}$ is useful to allow the model to match the actual aggregate share of government spending in the economy. In order to finance its expenditures, the government levies proportional taxes on consumption, $\tau_{c}$, on labor income and profits, $\tau$, and on capital income, $\tau_{k}$.

\subsection{Households}

Human capital accumulation. Individuals are heterogeneous with respect to their entrepreneurial ability, $h_{e}$, which is the capacity of agents to employ capital and labor more or less productively. Households are also heterogeneous with respect to their efficiency units of labor, $h_{w}$. We assume that the initial distribution of $h_{e}$ follows a log-normal distribution with location parameter $\mu_{e}$ and scale parameter $\sigma_{e}$; while the initial distribution of $h_{w}$ follows a log-normal distribution with location parameter $\mu_{w}$ and scale parameter $\sigma_{w}$. Individuals can enhance their future skills by investing in human capital accumulation. The law of motion for $h_{w}$ and $h_{e}$ are given by:

$$
\begin{gathered}
h_{w}^{\prime}=\xi_{w}\left(h_{w} x_{w}\right)^{\psi_{w}}+\left(1-\delta_{h}\right) h_{w}, \\
h_{e}^{\prime}=\xi_{e}\left(h_{e} x_{e}\right)^{\psi_{e}}+\left(1-\delta_{h}\right) h_{e},
\end{gathered}
$$


where $\delta_{h}$ is the depreciation rate and $\left(x_{w}, x_{e}\right)$ denote investments in working and entrepreneurial ability, respectively. Since human capital investment is intensive in time, we assume that $\left(x_{w}, x_{e}\right)$ are denoted in units of time. This corresponds to onthe-job training human capital accumulation. To keep the model tractable, workers are not allowed to invest in their entrepreneurial ability and entrepreneurs are not allowed to invest in their ability as workers.

Budget constraints. In each period of life, and conditional on the career choice, individuals make decisions about asset accumulation and investments in human capital. Individuals' labor productivity in the private sector is determined by an ageefficiency index given by $h_{w, t} \exp \left(s_{t}\right)$, where $s_{t}$ is a random component that evolves according to an $\mathrm{AR}(1)$ process given by $s_{t}=\rho s_{t-1}+\varepsilon_{t}$ with innovations $\varepsilon_{t} \sim N\left(0, \sigma_{\varepsilon}^{2}\right)$. Analogously, the evolution of labor productivity in the public sector is represented by $h_{w, t} \exp \left(s_{g, t}\right)$, where $s_{g, t}$ is an $\operatorname{AR}(1)$ process given by $s_{g, t}=\rho_{g} s_{g, t-1}+\varepsilon_{g, t}$ with innovations $\varepsilon_{g, t} \sim N\left(0, \sigma_{\varepsilon_{g}}^{2}\right)$. This is to be consistent with the fact that labor legislation regarding, for instance, firing might be different for civil servants when compared to private workers (Fact 3). This might also be consistent with differences in job characteristics of the two sectors.

We can write individual's earnings (before taxes) in occupation $m \in\{c s, w k, e\}$ as:

$$
\tilde{y}_{m, t}= \begin{cases}(1+\zeta) w h_{w, t} \exp \left(s_{g, t}\right)\left(1-x_{w, t}\right), & \text { if civil servant }(m=c s) ; \\ w h_{w, t} \exp \left(s_{p, t}\right)\left(1-x_{w, t}\right), & \text { if private sector worker }(m=w k) ; \\ \Pi_{t}\left(a_{t}, h_{e, t}\left(1-x_{e, t}\right)\right), & \text { if entrepreneur }(m=e) .\end{cases}
$$

Parameter $\zeta$ corresponds to the wage premium that public sector workers receive relative to their counterparts in the private sector. Individuals can resort to selfinsurance to protect themselves against the uncertainty on labor income. They can trade an asset subject, which is denoted by $a_{t}$ and takes the form of capital. Agents are not allowed to incur debt at any age, so that the amount of assets carried over from age $t$ to $t+1$ is such that $a_{t+1} \geq 0$. Furthermore, given that there is no altruistic bequest motive and death is certain at the age $T+1$, agents in the end of their life consume all their available resources, that is, $a_{T+1}=0$. At period $t$ the budget 
constraint of an active individual is given by:

$$
\left(1+\tau_{c}\right) c_{m, t}=\left[1+\left(1-\tau_{k}\right) r\right] a_{m, t}+(1-\tau) \tilde{y}_{m, t}-I_{A, t} \theta-a_{m}^{\prime}
$$

for $m \in\{c s, w k, e\}$. We assume that (e.g., constitutional rules) the hiring process for civil servants is provided by public competition. Agents in the private sector who want to work in the public sector must take open exams and only those who obtain the best grades on these tests become eligible to fill a pre-determined number of job positions. We assume that the score, $q_{t}$, of an individual who decides to take one of those exams is a random variable with $U[0,1]$. In addition, the cost that an individual who applies for a public sector job faces is captured by the variable $\theta$, and $I_{A, t}$ is an indicator function that takes value 1 if she chooses to apply for a public job and 0 otherwise.

The timeline of events in the public sector recruitment is as follows. An individual who decides to apply for a public sector job at age $t$ faces the cost $\theta$ in $t$ but will find out her score at beginning of age $t+1$. The individual then can only choose to work for the government in the case that $q_{t+1} \geq \bar{q}$, where $\bar{q}$ is the selection criterion that can be used by the government to balance demand and supply of jobs in the government sector. Therefore, related to the matching model literature (e.g., Mortensen and Pissarides, 1994), $\theta$ is a search cost and $q_{t}$ is the probability of finding a job offer, which depends on the number of vacancies. We could conditioned the entry to a public sector job by the individual human capital level and ability shock. We use the above approach to simplify the analysis. Also, we view the public sector as a continuous of different jobs which would require different levels of human capital. The fixed lump-sum cost to apply for a public job implies that in equilibrium the decision to apply for a public job will be correlated with individual's human capital, shocks and assets. In addition, the present approach would in some way understate the effects of an overpaid public sector on misallocation and efficiency.

At age $T_{r}$, agents retire and start collecting social security payments at an exogenously specified replacement rate of the last period earnings. Consistent with Fact 2 above, there are two main differences in the calculation of retirement benefits in each sector. First, the replacement rate, $\eta_{m}$, in the public sector is higher than in the private sector. Second, benefits in the private sector are capped by a limit denoted by $\bar{b}$, while there is no benefit cap in the public sector. Thus, the budget constraint for retirees can 
be written as follows:

$$
\left(1+\tau_{c}\right) c_{m, t}=\left[1+\left(1-\tau_{k}\right) r\right] a_{m, t}+b_{m, t}-a_{m}^{\prime}
$$

where $b_{m, t}$ denotes the benefits and is given by:

$$
b_{m, t}= \begin{cases}\eta_{r g} \tilde{y}_{c s, T_{r}-1}, & \text { if retired in the public sector; } \\ \eta_{r p} \min \left\{\tilde{y}_{\tilde{m}, T_{r}-1}, \bar{b}\right\}, \tilde{m} \in\{w k, e\}, & \text { if retired in the private sector. }\end{cases}
$$

Recursive formulation of individuals' problems. Let $V_{m, t}\left(\omega_{t}\right)$ denote the value function of an individual aged $t$ in the occupation $m$, where $\omega_{t}=\left(a_{t}, h_{w, t}, h_{e, t}, s_{t}, z_{t}\right)$ is the individual state space. In addition, considering that agents die at age $T$ and that there is no altruistic link across generations, we have that $V_{m, T+1}\left(\omega_{T+1}\right)=0$. Thus, the choice problem of individuals aged $t$ who work in the private sector can be recursively represented as follows: 25

$$
\begin{aligned}
V_{w, t}(\omega)= & \underset{a_{w}^{\prime} \geq 0, x_{w} \geq 0, I_{A, t} \in\{0,1\}}{\operatorname{Max}}: u\left(c_{w}\right)+ \\
& \beta\left[I_{A, t} P(q \geq \bar{q}) E_{s^{\prime}} \max \left\{V_{c s, t+1}\left(\omega^{\prime}\right), V_{w, t+1}\left(\omega^{\prime}\right), V_{e, t+1}\left(\omega^{\prime}\right)\right\}+\right. \\
& {\left.\left[1-I_{A, t} P(q \geq \bar{q})\right] E_{s^{\prime}} \max \left\{V_{w, t+1}\left(\omega^{\prime}\right), V_{e, t+1}\left(\omega^{\prime}\right)\right\}\right], }
\end{aligned}
$$

subject to (26), where $\omega^{\prime}=\left(a^{\prime}, h_{w}^{\prime}, h_{e}^{\prime}, s^{\prime}, z^{\prime}=1\right)$. Analogously, the recursive problem of individuals who are entrepreneurs can be represented by:

$$
\begin{aligned}
V_{e, t}(\omega)= & \underset{a_{e}^{\prime} \geq 0, x_{e} \geq 0, I_{A, t} \in\{0,1\}}{\operatorname{Max}}: u\left(c_{e}\right)+ \\
& \beta\left[I_{A, t} P(q \geq \bar{q}) E_{s^{\prime}} E_{z^{\prime}} \max \left\{V_{c s, t+1}\left(\omega^{\prime}\right), V_{w, t+1}\left(\omega^{\prime}\right), V_{e, t+1}\left(\omega^{\prime}\right)\right\}+\right. \\
& {\left.\left[1-I_{A, t} P(q \geq \bar{q})\right] E_{s^{\prime}} E_{z^{\prime}} \max \left\{V_{w, t+1}\left(\omega^{\prime}\right), V_{e, t+1}\left(\omega^{\prime}\right)\right\}\right], }
\end{aligned}
$$

subject to (26), where $\omega^{\prime}=\left(a^{\prime}, h_{w}^{\prime}, h_{e}^{\prime}, s^{\prime}, z^{\prime}\right)$.

Civil servants do not need to apply again for a government job in order to con-

\footnotetext{
${ }^{25}$ In order to simplify the notation, we have suppressed the subscript for age from both the state and control variables.
} 
tinue working in the public sector. As a consequence, their problem can be written as follows:

$$
V_{c s, t}(\omega)=\underset{a_{c s}^{\prime} \geq 0, x_{c s} \geq 0}{\operatorname{Max}}: u\left(c_{c s}\right)+\beta E_{s^{\prime}} \max \left\{V_{c s, t+1}\left(\omega^{\prime}\right), V_{w, t+1}\left(\omega^{\prime}\right), V_{e, t+1}\left(\omega^{\prime}\right)\right\},
$$

subject to (26), where $\omega^{\prime}=\left(a^{\prime}, h_{w}^{\prime}, h_{e}^{\prime}, s^{\prime}, z^{\prime}=1\right)$.

Finally, since retires only choose their next period assets, their problem is very straightforward and can be written as follows:

$$
V_{m, t}\left(a_{m}\right)=\underset{a_{m}^{\prime} \geq 0}{\operatorname{Max}}: u\left(c_{m}\right)+\beta V_{m, t+1}\left(a_{m}^{\prime}\right),
$$

subject to (27) for $m=r g, r p$.

\subsection{Recursive competitive equilibrium}

At each point in time, agents differ from one another with respect to age $t$ and to state $\omega_{t}=\left(a_{t}, h_{w, t}, h_{e, t}, s_{t}, z_{t}\right) \in \Omega$. Agents of age $t$ identified by their individual states $\omega$, are distributed according to a probability measure $\lambda_{t}$ defined on $\Omega$, as follows. Let $\left(\Omega, \digamma(\Omega), \lambda_{t}\right)$ be a space of probability, where $\digamma(\Omega)$ is the Borel $\sigma$-algebra on $\Omega$ : for each $\eta \subset F(\Omega), \lambda_{t}(\eta)$ denotes the fraction of agents aged $t$ that are in $\eta$.

Given the age $t$ distribution, $\lambda_{t}, Q_{t}(\omega, \eta)$ induces the age $t+1$ distribution $\lambda_{t+1}$ as follows. The function $Q_{t}(\omega, \eta)$ determines the probability of an agent at age $t$ and state $\omega$ to transit to the set $\eta$ at age $t+1$. $Q_{t}(\omega, \eta)$, in turn, depends on the policy functions in (28), and on the exogenous stochastic process for $z$. Now, we have all the tools to characterize the stationary recursive competitive equilibrium. Households' optimal behavior was previously described in detail above as well as the problem in the corporate sector, non-corporate sector and the government sector. It remains, therefore, to characterize the market equilibrium conditions, the aggregate law of motion, and the government budget constraint. In each period, there are three prices in this economy $(w, r, R)$, but $R=r+\delta$. The equilibrium in the labor and capital 
markets are defined by:

$$
\begin{aligned}
K=\sum_{t=1}^{T_{R}} \mu_{t} \int_{\Omega} d_{e, t}(\omega) k_{t}(\omega) d \lambda_{t}+K_{c} & =\sum_{t=1}^{T} \mu_{t} \int_{\Omega} d_{m, t} a_{m, t}(\omega) d \lambda_{t} \\
N_{p}=\sum_{t=1}^{T_{R}} \mu_{t} \int_{\Omega} d_{e, t}(\omega) n_{t}(\omega) d \lambda_{t}+N_{c} & =\sum_{t=1}^{T_{R}} \mu_{t} \int_{\Omega} d_{w, t}(\omega) h_{w, t}(\omega) \exp \left(s_{p, t}\right)\left(1-x_{w, t}(\omega)\right) d \lambda_{t}, \\
N_{g} & =\sum_{t=1}^{T_{R}} \mu_{t} \int_{\Omega} d_{c s, t}(\omega) h_{w, t}(\omega) \exp \left(s_{g, t}\right)\left(1-x_{w, t}(\omega)\right) d \lambda_{t} .
\end{aligned}
$$

The consumption tax rate, $\tau_{c}$, is such that it balances the government's budget,

$$
C_{g}+I_{g}+(1+\zeta) w N_{g}+B=\tau\left(w N_{p}+(1+\zeta) w N_{g}+\Pi\right)+\tau_{k} r K_{p}+\tau_{c} C,
$$

where $C$ denotes aggregate consumption, $\Pi$ represents aggregate profits and $B$ denotes total benefits. Finally, given the decision rules of households, $\lambda_{t}(\omega)$ satisfies the following law of motion:

$$
\lambda_{t+1}(\eta)=\int_{\Omega} Q_{t}(\omega, \eta) d \lambda_{t} \forall \eta \subset \digamma(\Omega)
$$

\section{Quantitative Analysis}

In order to study quantitatively the effects of a generous civil servant compensation and government reforms which would change the pension and wage scheme of public employees on economic efficiency, we must assign values for model parameters. We proceed by calibrating and estimating parameters such that the model economy matches key micro and macro statistics of the Brazilian economy. Brazil is an interesting case since it has a large public-private earnings premium. The model, however, is sufficiently general to be applied to other countries, such as Spain, Portugal, India, among others. Below is the description of how we set the value of parameters. 


\subsection{Calibration and estimation}

Table 1 lists the value of each parameter for the Brazilian economy and includes a comment on how each was selected.

Model period and age distribution: The model period is one year. We assume that individuals start their lives at the age of 25 and live until the age of 80 . Therefore, the extension of individuals' lifetime in the model is 56 periods $(\mathrm{T}=56)$. The age population distribution, $\left\{\mu_{t}\right\}_{t=1}^{T}$, is obtained from the 2008 Brazilian households survey (PNAD). Figure 3 shows the population distribution by age for 2008.

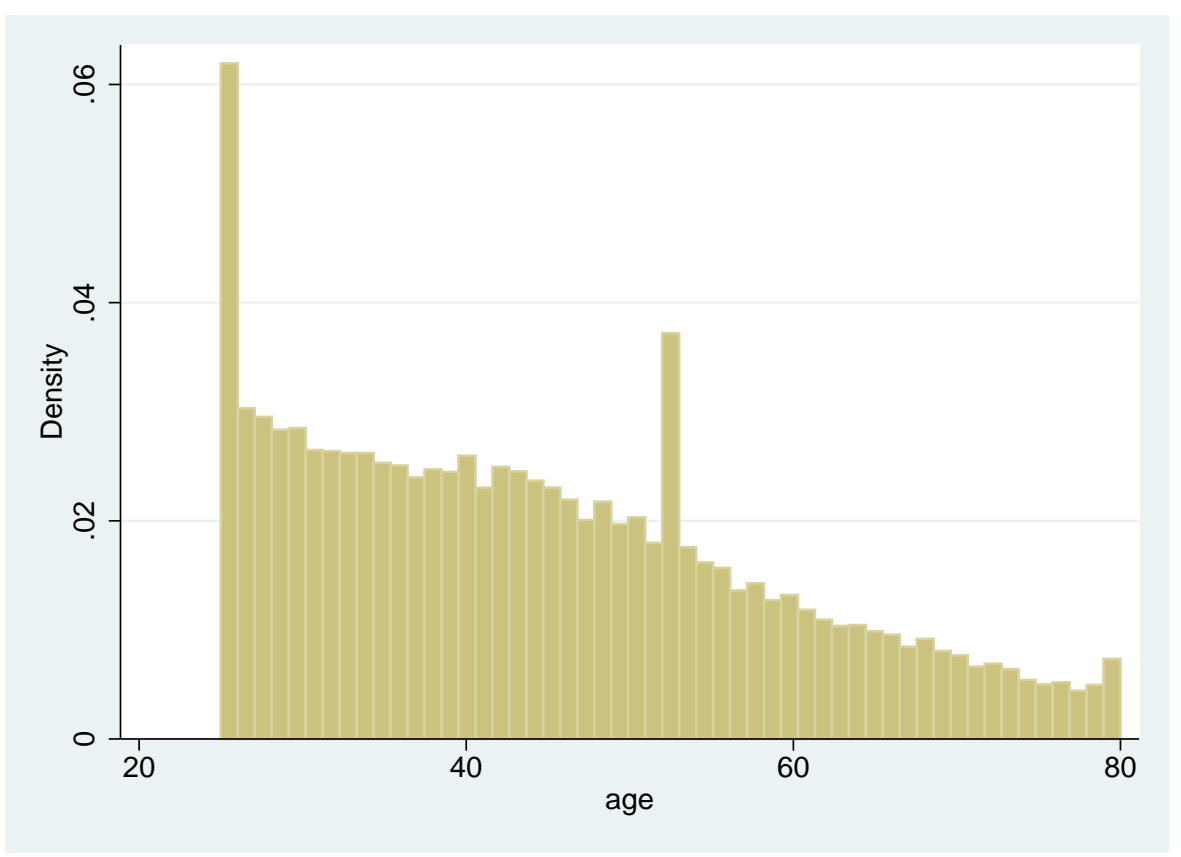

Figure 3: Age population distribution. Source: 2008 PNAD.

Utility: There are two parameters related to preferences, $(\beta, \gamma)$. The intertemporal discount factor, $\beta$, is calibrated such that the capital-to-output ratio is about $2.5 .^{26}$ The coefficient of relative risk aversion, $\gamma$, is set at 2.0 , which is consistent with the evidence in Mehra and Prescott (1985).

Production technologies: We set $\varphi$ and $v$ so that in the entrepreneurial sector $54 \%$ of income is paid to labor, $36 \%$ is paid to remunerate capital, and $10 \%$ are profits.

\footnotetext{
${ }^{26}$ Using the Heston, Summers, and Aten (2012) Penn World Tables 7.1 and the inventory method, we find a value of 2.5 for the capital-to-output ratio in the Brazilian economy.
} 
Therefore, $\varphi=0.40$ and $v=0.90$. In the corporate sector, we set $\alpha=0.36$. These values are consistent with the numbers provided by Gollin (2002). In addition, we assume that the capital stock depreciates at a rate of $6 \%$ per year, which is consistent to the figures used in the growth and development literature (cf., Parente and Prescott, 2000). We also set $\delta_{g}=0.06$. According to the Brazilian Institute of Geography and Statistics (IBGE), the ratio of public goods to output is roughly $16 \%$ - using information on production costs. Then, in order to match this ratio we set $A_{g}=0.85$. To calibrate parameter $\chi$, we rely on estimates provided by Hulten (1996) who uses a cross-section of low income countries including Latin American countries and obtains a point estimate of 0.1 for $\chi$, which is the value we use. We set the business risk $\Delta=0.04$ such that we match the exit rate in Brazil and we calibrate $\phi$ such that the share of entrepreneurs in the labor force is equal to 4.7. See Table 7 in Appendix A.

Stochastic process on labor productivity: The parameters that characterize the stochastic component of individuals labor productivity are: $\rho, \sigma_{\varepsilon}^{2}, \rho_{g}, \sigma_{\varepsilon_{g}}^{2}$. For computational reasons, we use the algorithm described in Tauchen (1986) to approximate these stochastic processes for each sector by a first-order Markov chain with 3 points. Since there is no household panel dataset for Brazil comparable with the Panel Study of Income Dynamics (PSID) in the United States, we can not obtain direct estimates for the persistence parameters, $\rho$ and $\rho_{g}$. Thus, what we do is to use information on average tenure in each sector along with data on the distribution of residual wages to calibrate them. In particular, from the Mincerian regressions presented in Table 8 (columns (6) and (7)), we have that the residual variance for civil servants and private workers are nearly the same: $\sigma_{s}^{2}=\frac{\sigma_{\varepsilon}^{2}}{1-\rho}=0.4279$ and $\sigma_{s_{g}}^{2}=\frac{\sigma_{\varepsilon_{g}}^{2}}{1-\rho_{g}}=0.4290 .{ }^{27}$ We calibrate $\rho$ and $\rho_{g}$ in such a way that the average time that individuals take to change position in the grids for $s$ and $s_{g}$ are consistent with the average tenure in each sector, which is about 13 years for public employees and 7 years for private workers. This procedure entails that $\left(\rho, \sigma_{\varepsilon}^{2}\right)=(0.88,0.089)$ and $\left(\rho_{g}, \sigma_{\varepsilon_{g}}^{2}\right)=(0.98,0.016) .{ }^{28}$ These figures are consistent with the fact that public sector wages are more stable and more compressed than in the private sector. This implies that workers facing bad (good) shocks in the pub-

${ }^{27}$ The estimation procedure is presented in Appendix A.

${ }^{28}$ The associated grids for $s_{g}$ and $s$ are $\{-0.3752,0,0.3752\}$ and $\{-0.8955,0,0.8955\}$, respectively. In addition, the transition matrix in the public sector is $\left(\begin{array}{llll}0.9251 & 0.0749 & 0.0000 \\ 0.0668 & 0.8664 & 0.0668 \\ 0.0000 & 0.0749 & 0.9251\end{array}\right)$, while $\left(\begin{array}{lll}0.8729 & 0.1271 & 0.0000 \\ 0.0668 & 0.8664 & 0.0668 \\ 0.0000 & 0.1271 & 0.8729\end{array}\right)$ is the transition matrix in the private sector. 
lic sector are better-off (worse-off) than their comparable counterparts in the private sector. $^{29}$

Human capital functions: We calibrate the parameters of the initial skill distribution of newborn agents, $\mu_{w}$ and $\sigma_{w}$ for working ability and $\mu_{e}$ and $\sigma_{e}$ for entrepreneurial ability, to match the wage distribution of workers and entrepreneurs, respectively, at age 25, which is the age individuals are born in the model. The parameters of the human capital functions are calibrated as follows. First, given that the evidence for the human capital depreciation rate ranges from 0.0016 to 0.089 , with most of the estimates concentrated around 0.04 (Browning, Hansen, and Heckman, 1999), we set $\delta_{h}=0.04$. As is usual in the macro-labor literature, the other parameters are then chosen in order to approach the simulated earnings profiles to their counterparts estimated from the data. ${ }^{30}$ This procedure is carried out for workers and entrepreneurs and we obtain $\left(\psi_{w}, \psi_{e}\right)=(0.50,0.75)$ and $\left(\xi_{w}, \xi_{e}\right)=(0.14,0.17) .{ }^{31}$ The resulting profiles are presented in Figure 4. As a matter of goodness of the fit, we calculate the average (percentage) deviation, in absolute terms, between the model implied earnings profiles and the data. By this measure, on average the model implied earnings profiles differ from the data by $2.57 \%$ in the case of workers and by $3.48 \%$ in the case of entrepreneurs.

Public sector parameters: Based on Paes and Bugarin (2006), we assume a labor income tax rate of $18 \%$ and a capital tax of $15 \%$. The consumption tax is determined in such a way that the government budget balances in equilibrium, which implies a tax rate equal to $32 \%$ in the benchmark economy. The replacement rate in the public sector, $\eta_{r g}$, is equal to one, while in the private sector, $\eta_{r p}$, it is equal to 0.82 , which are consistent with the OECD (2011) report, Government at a Glance. We also impose a ceiling in private pensions, $\bar{b}$, such that the maximum pension in the private sector is about $16 \%$ of the one paid in the public sector. This is the number we found directly from the Brazilian households survey data. We set the public wage premium

\footnotetext{
${ }^{29}$ For the sake of comparison, Kaplan (2012) estimates similar stochastic process for labor productivity in the U.S. and finds a value of 0.94 for the persistence parameter, which is the median point of the values we found. The role of government jobs in providing insurance is studied in Reis and Zilberman (2014). He, Huang, Liu, and Zhu (2014) provide evidence on differences in precautionary savings between public employees and other workers in the Chinese economy.

${ }^{30}$ See, for example, Wallenius (2011) and Huggett, Ventura, and Yaron (2006).

${ }^{31}$ Estimates of the elasticity parameters $\left(\psi_{w}, \psi_{e}\right)$ are surveyed by Browning, Hansen, and Heckman (1999). These estimates range from 0.5 to almost 1.0. Thus, we restrict our search to this interval. In the case of the scale parameters, $\left(\xi_{w}, \xi_{e}\right)$, we consider values in the interval $[0.05,0.20]$.
} 
Table 1: Estimation and calibration of model parameters: Brazilian economy

\begin{tabular}{|c|c|c|c|}
\hline \multicolumn{4}{|c|}{ External calibration } \\
\hline Parameter & Description & Values & Source \\
\hline$\gamma$ & Risk aversion & 2 & Mehra and Prescott (1985) \\
\hline$\varphi$ & Importance of capital & 0.4 & Gollin (2002) \\
\hline$v$ & Returns to scale & 0.9 & IBGE \\
\hline$\chi$ & Importance of infrastructure & 0.1 & Hulten (1996) \\
\hline$\alpha$ & Capital share - corporate sector & 0.36 & Gollin (2002) \\
\hline$\delta=\delta_{g}$ & Depreciation rate & 0.06 & Growth literature \\
\hline$\zeta^{0}$ & Public-sector wage premium & 0.25 & PNAD survey \\
\hline$\delta_{h}$ & Depreciation rate, human capital & 0.04 & Browning, Hansen, and Heckman (1999) \\
\hline$\mu_{w}$ & Location par., initial $h_{w}$ & 1.15 & PNAD survey \\
\hline$\sigma_{w}$ & Scale par., initial $h_{w}$ & 0.78 & PNAD survey \\
\hline$\mu_{e}$ & Location par., initial $h_{e}$ & 2.06 & PNAD survey \\
\hline$\sigma_{e}$ & Scale par., initial $h_{e}$ & 0.90 & PNAD survey \\
\hline$\tau$ & Income tax rate & $18 \%$ & Paes and Bugarin (2006) \\
\hline$\tau_{k}$ & Capital income tax rate & $15 \%$ & Paes and Bugarin (2006) \\
\hline$\eta_{r g}$ & Replacement rate, pub. sector & 1 & OECD (2012) \\
\hline$\eta_{r p}$ & Replacement rate, priv. sector & 0.82 & OECD (2012) \\
\hline$\rho$ & Persistence, priv. sector & 0.88 & Average tenure, priv. sector \\
\hline$\sigma_{\epsilon}^{2}$ & Variance of innovation, priv. sector & 0.089 & Match residual inequality \\
\hline$\rho_{g}$ & Persistence, pub. sector & 0.98 & Average Tenure, pub. sector \\
\hline$\sigma_{\epsilon_{g}}^{2}$ & Variance of innovation, pub. sector & 0.016 & Match residual inequality \\
\hline \multicolumn{4}{|c|}{ Internal calibration } \\
\hline Parameter & Description & Values & Source \\
\hline$\beta$ & Discount factor & 0.98 & Capital to output ratio, 2.5 \\
\hline$\phi$ & Enforcement parameter & 0.40 & Share of entrepreneurs, $4.7 \%$ \\
\hline$\xi_{w}$ & Human capital productivity & 0.14 & Life cycle workers' income \\
\hline$\xi_{e}$ & Human capital productivity & 0.17 & Life cycle entr.' income \\
\hline$\psi_{w}$ & On the job training parameter & 0.50 & Life cycle workers' income \\
\hline$\psi_{e}$ & On the job training parameter & 0.75 & Life cycle entr.' income \\
\hline$\Delta$ & Business risk & 0.04 & exit rate, IBGE \\
\hline$\theta$ & Cost of applying for a public job & 1.63 & $\begin{array}{l}\text { Flow of individuals aged } 30-34 \\
\text { from private to public jobs }\end{array}$ \\
\hline $\bar{q}$ & Government selection criteria & 0.84 & Share of public servants \\
\hline$\tau_{c}$ & Consumption tax & 0.32 & Balance gov. budget constraint \\
\hline$A_{g}$ & TFP - Government sector & 0.85 & Share of public goods \\
\hline $\bar{b}$ & Ceiling for retiree income, priv. sector & $\frac{b_{-s}^{m}}{b_{c s}^{\max }}=0.16$ & PNAD survey \\
\hline$C_{g}$ & Unproductive government spending & $3 \%$ of $Y$ & Aggregate government spending \\
\hline
\end{tabular}



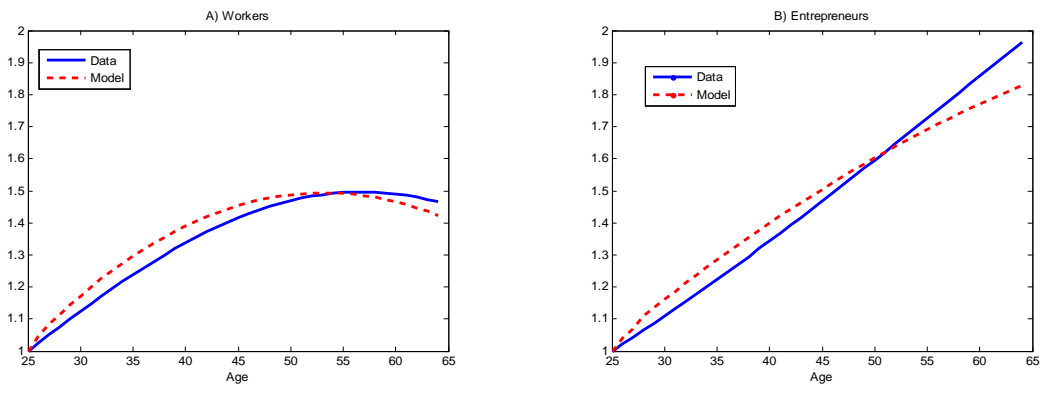

Figure 4: Average earnings profile. Panel A) displays the workers average earnings profile, while Panel B) displays the earnings profile of entrepreneurs. In both cases, we present the simulated profiles under the baseline calibration and the actual ones. The average earnings at age 25 were normalized to 1.

Table 2: Basic statistics: Brazil and baseline economy. Sources: IBGE - National accounts and PNAD.

\begin{tabular}{lcc}
\hline \hline Variable & Brazil & Baseline model \\
\hline \% of entrepreneurs & 4.50 & 4.69 \\
\% of civil servants & 10 & 10.03 \\
Share of public goods & 0.16 & 0.17 \\
Capital to output ratio & 2.50 & 2.53 \\
Income Gini (all individuals) & 0.51 & 0.523 \\
Income Gini (private workers) & 0.46 & 0.471 \\
Income Gini (civil servants) & 0.48 & 0.488 \\
Income Gini (Entrepreneurs) & 0.53 & 0.544 \\
\hline
\end{tabular}

for workers to be equal to $\zeta=0.25$, which is consistent with the conditional public wage premium provided in regression (4), Table 8 in Appendix A. Two parameters remain to be set: the cost of applying for a public sector job, $\theta$, and the government selection criteria, $\bar{q}$. We set them to minimize the distance between the model and the data. In particular, we use as targets the public sector employment as a share of total employment and the average flow of individuals aged 30-34 going from the private sector to the public sector. This last measure is taken from the Brazilian monthly employment survey (PME). ${ }^{32}$

The model matches the Brazilian economy fairly well along a number of dimensions that were calibrated, as well as some statistics that were not calibrated, such as the income Gini index for workers and entrepreneurs. Table 2 presents some data

\footnotetext{
${ }^{32}$ We do not have data on all individuals applying for public jobs. This explains why we use the flow of individuals aged 30-34 going from the private sector to the public sector to set some government parameters of the model.
} 

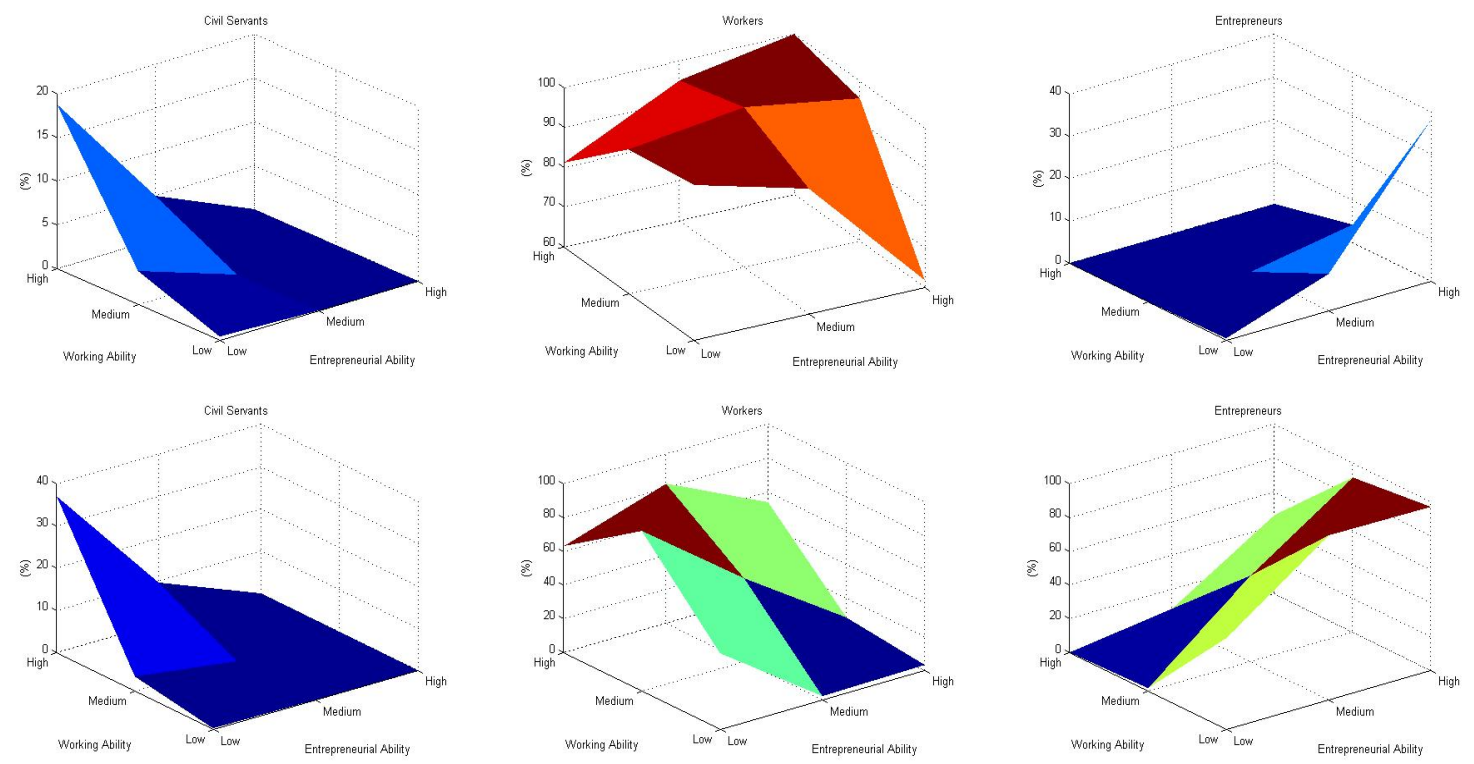

Figure 5: Occupational choice for different levels of productivity. First row: Bottom decile of wealth. Second row: Top decile of wealth.

statistics and the model counterpart. Observe that the share of public goods and the percent of civil servants in the labor force are similar in the model and in the data. The aggregate cost of job applications to public jobs, which we label as the rent seeking cost, is significative in the baseline economy. It is roughly 10 percent of income. Number reported in Table 3. We do not have this measure for the Brazilian economy; however, there is a large number in Brazil of education institutions to prepare individuals to undertake a public exam for a public job. In our model, $\theta$ is in units of the consumption good, but in mapping this to the data we should also consider the time individuals spend in preparing for such exams and therefore their foregone income. ${ }^{33}$

Finally, Figure 5 shows the occupational choice of the agents for different levels of entrepreneurial and labor productivity. The first row contains the fraction of agents in each occupation in the bottom decile of wealth, while the second row plots the occupational decision in the top decile of wealth. Notice the sharp difference between the two graphs in the last column which contains the fraction of entrepreneurs. If

\footnotetext{
${ }^{33}$ According to ANPAC (Brazilian National Agency for Protection and Support to Public Exams), a non-governmental institution, there are about 12 million Brazilians ( $5 \%$ of the population and more than $10 \%$ of the labor force) taking exams for a public job. This number includes also workers who already have a public job but are trying to upgrade to a better paid one. In our baseline economy, there are 4.6 percent of workers applying for a public jog and therefore it does not seem that we are overestimating the number of applications to a public job.
} 
there was no enforcement problem in entrepreneurial activity, then the share of entrepreneurs in the space $\left(h_{e}, h_{w}\right)$ should have been similar for both deciles of wealth. In both graphs, agents with a very high entrepreneurial ability are becoming entrepreneurs, but observe that the share of entrepreneurs is higher for agents in the top decile of wealth than in the bottom decile of wealth. Regarding the decision to become civil servant (first row), we can see that those are characterized mainly by individuals with a low entrepreneurial ability and high labor productivity. In addition, the fraction of entrepreneurs in the top decile of assets is significantly higher than in the bottom decile of wealth.

\subsection{Counterfactual exercises}

Now, with all parameters set we can perform different policy simulations. Firstly, we change the public sector wage premium. Then, we align the social security system of the public sector such that it becomes similar to the system faced by workers and entrepreneurs in the private sector. Finally, we change the stochastic process of the idiosyncratic productivity in the public sector such that it becomes closer to those faced by workers in the private sector.

\subsubsection{The effects of reducing the public sector wage premium}

Figure 6 displays results for two experiments. See also Table $3 .^{34}$ In the first one, Exp. $1 \mathrm{~A}$, we only change the public sector wage premium and keep all other parameters at their baseline value. The reduction in $\zeta$ has an inverted U-shape effect on aggregate output. In order to understand this, notice that a smaller wage premium attracts fewer workers to a public sector job (see the percent of public employees on Table 3). However, because of higher income uncertainty and a less generous retirement pension in the private sector, individuals have more incentive to save. Hence, as one can see in Table 3, aggregate capital increases. On the other hand, the fall in public sector employment reduces the supply of public infrastructure, $G$, and therefore has a negative effect on private production. Experiment $1 \mathrm{~A}$ shows that for reductions in $\zeta$ up to 10 percentage points from the baseline value (from $25 \%$ to $15 \%$ ), the former effect

\footnotetext{
${ }^{34}$ Table 3 describes the effects of policy changes on several variables such as factor prices, aggregate capital stock, the consumption tax rate, aggregate cost of applying for a public job, among other variables.
} 


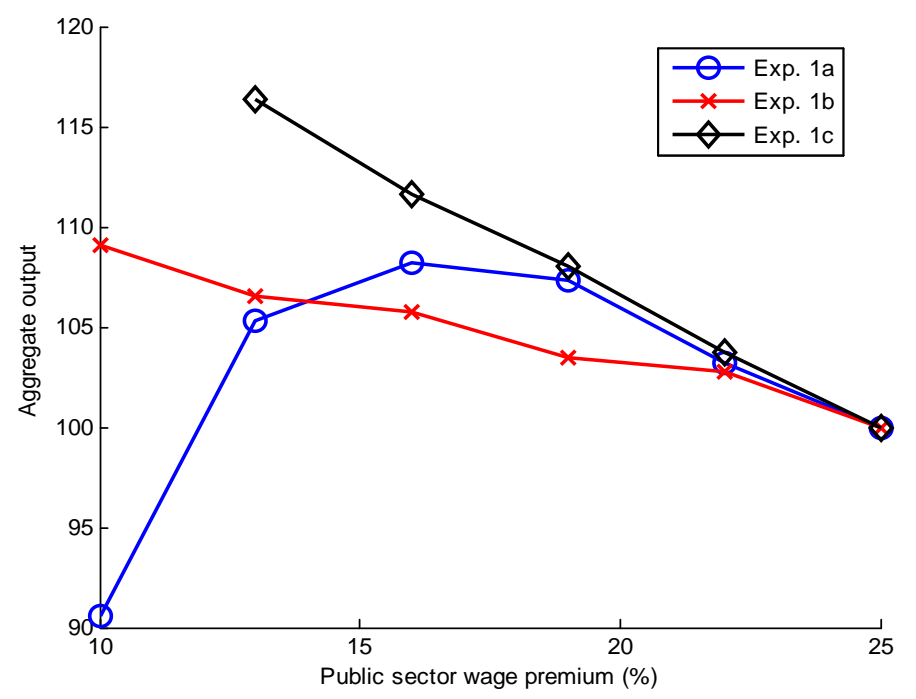

Figure 6: Aggregate output by public sector wage premium. In Experiment 1A, we only change the public sector wage premium, $\zeta$; In Experiment $1 \mathrm{~B}$, we change $\zeta$, but adjust $\theta$ in order to keep the share of individuals in the public sector constant; In Experiment $1 \mathrm{C}$, we do the same thing as in Experiment $1 \mathrm{~B}$, but instead of adjusting $\theta$, we adjust $\bar{q}$ to keep the share of individuals in the public sector constant.

dominates and output increases by as much as $8 \%$. However, if the wage premium is reduced further, the later effect dominates and consequently aggregate output falls. In fact, the model predicts that a public-private wage premium of $\zeta=10 \%$ would decrease output by nearly $10 \%$ in comparison to the benchmark case. Therefore, only reducing the attractiveness of the public sector does not necessarily increase aggregate output, since public infrastructure might be seriously reduced.

Experiments $1 \mathrm{~B}$ and $1 \mathrm{C}$ show the effects of reducing the wage premium when we keep the share of civil servants unchanged. In Experiment 1B, for each value of $\zeta$, we adjust the cost of applying for a public sector job, $\theta$, in order to maintain the share of individuals working in the public sector constant. ${ }^{35}$ As one can see in Figure 6 , when we reduce the wage premium from its benchmark value to $22 \%$ or $19 \%$, output still increases but by less than in Experiment 1A. Even though the share of civil servants is kept nearly constant, the level of public goods, $G$, decreases as we reduce $\zeta$. To understand this latter result, one should have in mind that the share of high ability individuals is larger in the public sector than in the private sector

\footnotetext{
${ }^{35}$ We also have results in which we keep the production of public infrastructure constant. Results are close to what are presented here and therefore for the sake of space we do not report them. They are available from the authors upon request.
} 
since ability is correlated with income and assets. Applying for a public sector job is costly and therefore households accumulate assets in order to apply for such a job. However, as the wage premium falls, the relative number of applications of individuals in lower levels of the skill distribution rises since the lump-sum cost $\theta$ decreases, reducing the average labor productivity in the public sector, but increasing it in the private sector. There is a reallocation of workers in the economy, which reduces public infrastructure. In contrast with Experiment $1 \mathrm{~A}$, it is interesting to note that if we continue reducing $\zeta$ and thus making the public sector job less attractive, output continues to go up in experiment $1 B$ as oppose to what happens in Experiment $1 A$. Not only the deadweight cost to apply for a public job decreases, but there is a reallocation of labor in the economy with a positive effect on aggregate output. ${ }^{36}$ The increase in aggregate output is larger than the decrease in the rent seeking cost in 2.3 percentage points and this increase is due to an increase in the efficiency in the economy. Notice that the consumption tax rate decreases with reductions in $\zeta$.

Experiment $1 C$ is similar to experiment $1 B$, but instead of adjusting $\theta$ to keep the share of civil servants unchanged, we adjust the government selection criteria, $\bar{q}$. Related to the matching literature, this would be similar to an increase in the number of matching. ${ }^{37}$ In this case, Figure 6 shows that as we reduce the wage premium, the aggregate output is always greater than in Experiments $1 A$ and $1 B$. To understand this result, note that now the share of applications falls as we reduce $\zeta$, which is due to the fact the we have kept $\theta$ at its benchmark value. Thus, as we decrease $\bar{q}$ to maintain public sector employment, we have that not only fewer individuals are applying for public sector jobs, but also fewer ones are failing the recruitment process. The flow in a public job increases and consequently the deadweight losses coming from applications to public jobs decrease substantially. Moreover, note that differently from the previous experiment, the supply of public goods raises, growing nearly $9 \%$ relative to the baseline when $\zeta=0.13$ - see Table 3 . This happens because the combination of a lower $\zeta$ with a constant $\theta$, entails the government in selecting a larger share of high productive individuals thereby raising labor productivity in the public sector. Interestingly, in this case not only aggregate output rises but public

\footnotetext{
${ }^{36}$ When $\zeta=0.13$, then $\theta=1.01$, which is nearly $38 \%$ lower than in the benchmark. The rent seeking cost decreases in $38 \%$. See Table 3 .

${ }^{37}$ Our view is that changing the probability of getting a job in the public sector is a more realistic exercise, but we report both exercises here.
} 
Table 3: Changing just the public sector wage premium. In Experiment $1 \mathrm{~A}$, we only change the public sector wage premium, $\zeta$; In Experiment $1 \mathrm{~B}$, we change $\zeta$, but adjust $\theta$ in order to keep the share of individuals in the public sector constant; In Experiment 1C, we do the same thing as in Experiment $1 \mathrm{~B}$, but instead of adjusting $\theta$, we adjust $\bar{q}$ to keep the share of individuals in the public sector constant.

\begin{tabular}{|c|c|c|c|c|c|}
\hline \multicolumn{6}{|c|}{ Experiment 1A } \\
\hline Variable & $\zeta=0.25$ & $\zeta=0.22$ & $\zeta=0.19$ & $\zeta=0.16$ & $\zeta=0.13$ \\
\hline$Y=Y_{c}+Y_{e}$ & 100 & 102.7 & 107.3 & 108.2 & 105.3 \\
\hline$Y_{e} / Y$ & $15.4 \%$ & $13.9 \%$ & $13.6 \%$ & $13.8 \%$ & $13.0 \%$ \\
\hline K & 100 & 103.4 & 109.8 & 111.3 & 110.5 \\
\hline$N_{p}$ & 100 & 104.9 & 111.2 & 113.6 & 119.1 \\
\hline$\%$ of civil servants & $10.03 \%$ & $8.12 \%$ & $5.81 \%$ & $4.49 \%$ & $1.76 \%$ \\
\hline$G / Y$ & $17.4 \%$ & $14.7 \%$ & $12.99 \%$ & $10.13 \%$ & $6.64 \%$ \\
\hline G & 100 & 86.57 & 80.70 & 62.47 & 40.12 \\
\hline$\tau_{c}$ & $32.3 \%$ & $24.9 \%$ & $20.8 \%$ & $13.0 \%$ & $4.34 \%$ \\
\hline$K_{c} / Y_{c}$ & 2.53 & 2.54 & 2.56 & 2.61 & 2.63 \\
\hline$w$ & 0.78 & 0.77 & 0.76 & 0.74 & 0.67 \\
\hline$r$ & $8.29 \%$ & $8.15 \%$ & $8.00 \%$ & $7.78 \%$ & $7.64 \%$ \\
\hline$\%$ of applications & $4.64 \%$ & $4.09 \%$ & $3.80 \%$ & $2.88 \%$ & $1.90 \%$ \\
\hline Rent seeking costs/Y & $10.04 \%$ & $8.63 \%$ & $7.61 \%$ & $5.80 \%$ & $3.90 \%$ \\
\hline \multicolumn{6}{|c|}{ Experiment 1B - Adjusting $\theta$} \\
\hline Variable & $\zeta=0.25$ & $\zeta=0.22$ & $\zeta=0.19$ & $\zeta=0.16$ & $\zeta=0.13$ \\
\hline$Y=Y_{c}+Y_{e}$ & 100 & 102.9 & 103.5 & 105.7 & 106.5 \\
\hline$Y_{e} / Y$ & $15.4 \%$ & $15.1 \%$ & $13.5 \%$ & $13.1 \%$ & $12.4 \%$ \\
\hline K & 100 & 103.8 & 104.3 & 108.2 & 109.3 \\
\hline$N_{p}$ & 100 & 103.2 & 103.5 & 105.4 & 105.6 \\
\hline$\%$ of civil servants & $10.03 \%$ & $10.01 \%$ & $10.04 \%$ & $10.09 \%$ & $10.13 \%$ \\
\hline$G / Y$ & $17.4 \%$ & $16.6 \%$ & $16.4 \%$ & $16.0 \%$ & $16.0 \%$ \\
\hline G & 100 & 98.09 & 97.78 & 97.25 & $98.24 \%$ \\
\hline$\tau_{c}$ & $32.3 \%$ & $30.2 \%$ & $29.5 \%$ & $28.5 \%$ & $28.3 \%$ \\
\hline$K_{c} / Y_{c}$ & 2.53 & 2.54 & 2.54 & 2.58 & 2.59 \\
\hline$w$ & 0.78 & 0.78 & 0.79 & 0.79 & 0.79 \\
\hline$r$ & $8.29 \%$ & $8.21 \%$ & $8.14 \%$ & $7.96 \%$ & $7.87 \%$ \\
\hline$\%$ of applications & $4.64 \%$ & $4.71 \%$ & $4.73 \%$ & $4.91 \%$ & $4.93 \%$ \\
\hline$\theta$ & 1.63 & 1.50 & 1.34 & 1.20 & 1.01 \\
\hline Rent seeking costs/Y & $10.04 \%$ & $9.12 \%$ & $8.13 \%$ & $7.38 \%$ & $6.21 \%$ \\
\hline \multicolumn{6}{|c|}{ Experiment $1 C$ - Adjusting $\bar{q}$} \\
\hline Variable & $\zeta=0.25$ & $\zeta=0.22$ & $\zeta=0.19$ & $\zeta=0.16$ & $\zeta=0.13$ \\
\hline$Y=Y_{c}+Y_{e}$ & 100 & 103.7 & 108.0 & 111.6 & 116.4 \\
\hline$Y_{e} / Y^{2}$ & $15.4 \%$ & $13.9 \%$ & $12.4 \%$ & $11.9 \%$ & $8.59 \%$ \\
\hline K & 100 & 104.5 & 111.3 & 117.0 & 118.0 \\
\hline$N_{p}$ & 100 & 103.6 & 106.6 & 108.9 & 113.6 \\
\hline$\%$ of civil servants & $10.03 \%$ & $10.00 \%$ & $10.10 \%$ & $10.10 \%$ & $10.04 \%$ \\
\hline$G / Y$ & $17.4 \%$ & $16.6 \%$ & $16.3 \%$ & $16.5 \%$ & $16.2 \%$ \\
\hline G & 100 & 99.16 & 101.06 & 105.8 & 108.8 \\
\hline$\tau_{c}$ & $32.3 \%$ & $30.7 \%$ & $31.6 \%$ & $33.0 \%$ & $38.0 \%$ \\
\hline$K_{c} / Y_{c}$ & 2.53 & 2.54 & 2.59 & 2.63 & 2.56 \\
\hline$w$ & 0.78 & 0.79 & 0.80 & 0.81 & 0.81 \\
\hline$r$ & $8.29 \%$ & $8.13 \%$ & $7.86 \%$ & $7.67 \%$ & $7.67 \%$ \\
\hline$\%$ of applications & $4.64 \%$ & $4.14 \%$ & $3.72 \%$ & $3.11 \%$ & $2.23 \%$ \\
\hline $\bar{q}$ & 0.85 & 0.828 & 0.787 & 0.728 & 0.53 \\
\hline Rent seeking costs/Y & $10.04 \%$ & $8.65 \%$ & $7.46 \%$ & $6.03 \%$ & $4.15 \%$ \\
\hline
\end{tabular}


infrastructure also increases. ${ }^{38}$

\subsubsection{The effects of aligning the social security regimes}

In Table 4, we show the effects of aligning the public and private social security regimes. In particular, we equate the retirement replacement rate in the public sector with its counterpart in the private sector and introduce the same cap on civil servants benefits that is observed for private sector workers. ${ }^{39}$ On the first half of Table 4, we show the results of this experiment when we adjust $\theta$ to keep the share of civil servants constant, while on the second half of this table, we present results when we adjust $\bar{q}$. For the sake of comparison, we also present results for changes in the wage premium - $\zeta$ reduces from $25 \%$ to $19 \%$.

As can be seen in this table, the effect of changing social security parameters in the public sector are large, with the output increasing by more than $8 \%$ in both cases. In order to understand this, observe that by making social security less generous, government induces private savings and thus increases capital accumulation. The aggregate capital stock goes up by nearly $16 \%$ in the long-run relative to the baseline when $\theta$ is adjusted. In this case, the capital-to-output ratio increases by roughly $7 \%$ and consequently the marginal productivity of labor and therefore the wage rate increases relatively to the baseline. Public infrastructure remains roughly constant and the tax rate on consumption decreases substantially in both cases. ${ }^{40}$

Next, we align as before the public sector system to its private counterpart and also decrease the public sector wage premium from $25 \%$ to $19 \%$. Results are shown in the last column of Table 4. There are important aggregate positive effects on output, capital accumulation and productivity. Notice that both production in the private and public sectors increase substantially when $\bar{q}$ is adjusted, and the tax rate on consumption is severely reduced. In this case, rent seeking costs as a share of income decreases by 6.5 percentage points while aggregate output increases by 19.4 percentage points.

Finally, in Figure 7, we show the welfare effects by individuals' working and entrepreneurial abilities of reducing the public sector wage premium (from $25 \%$ to $19 \%$ )

\footnotetext{
${ }^{38}$ When $\zeta$ decreases from 0.25 to 0.13 , then rent seeking costs as a share of income decreases by 6 percentage points, while aggregate output increases by 16 percentage points.

${ }^{39}$ More specifically, we change the replacement rate in the public sector from 1 to 0.82 and we introduce a cap in the pension such that this is the same as in the private sector. The ceiling changes proportionally with changes in income levels in the economy.

${ }^{40}$ The number of applications to a public job goes down.
} 
Table 4: Changing all factors. The second column displays results when we only change the wage premium to $19 \%$; The third column shows results when we align the parameters of the public and private social security systems; In the fourth column, we show results when we change all factors at the same time.

\begin{tabular}{|c|c|c|c|c|}
\hline \multicolumn{5}{|c|}{ Adjusting $\theta$} \\
\hline Variable & Baseline & Wage premium & Social Security & All \\
\hline$Y=Y_{c}+Y_{e}$ & 100 & 103.5 & 108.6 & 113.0 \\
\hline$Y_{e} / Y$ & $15.4 \%$ & $13.5 \%$ & $12.0 \%$ & 11.89 \\
\hline K & 100 & 104.3 & 115.9 & 123.1 \\
\hline$N_{p}$ & 100 & 103.5 & 105.6 & 110.2 \\
\hline$\%$ of civil servants & $10.03 \%$ & $10.04 \%$ & $9.99 \%$ & 10.18 \\
\hline$G / Y$ & $17.4 \%$ & $16.4 \%$ & $16.22 \%$ & $15.16 \%$ \\
\hline G & 100 & 97.78 & 101.2 & 98.5 \\
\hline$\tau_{c}$ & $32.3 \%$ & $29.5 \%$ & $23.85 \%$ & $20.50 \%$ \\
\hline$K_{c} / Y_{c}$ & 2.53 & 2.54 & 2.68 & 2.72 \\
\hline$w$ & 0.78 & 0.79 & 0.81 & 0.82 \\
\hline$r$ & $8.29 \%$ & $8.14 \%$ & $7.43 \%$ & $7.27 \%$ \\
\hline$\%$ of applications & $4.64 \%$ & $4.73 \%$ & $3.47 \%$ & $3.80 \%$ \\
\hline Rent seeking costs / Y & $10.04 \%$ & $8.13 \%$ & $7.41 \%$ & $5.60 \%$ \\
\hline \multicolumn{5}{|c|}{ Adjusting $\bar{q}$} \\
\hline Variable & Baseline & Wage premium & Social Security & All \\
\hline$Y=Y_{c}+Y_{e}$ & 100 & 108.0 & 108.1 & 119.4 \\
\hline$Y_{e} / Y$ & $15.4 \%$ & $12.4 \%$ & $12.7 \%$ & $9.77 \%$ \\
\hline K & 100 & 111.3 & 113.9 & 134.6 \\
\hline$N_{p}$ & 100 & 106.6 & 105.3 & 114.7 \\
\hline$\%$ of civil servants & $10.03 \%$ & $10.10 \%$ & $10.01 \%$ & $10.13 \%$ \\
\hline$G / Y$ & $17.4 \%$ & $16.3 \%$ & $16.21 \%$ & $15.09 \%$ \\
\hline G & 100 & 101.06 & 100.6 & $104.4 \%$ \\
\hline$\tau_{c}$ & $32.3 \%$ & $31.6 \%$ & $24.52 \%$ & $22.66 \%$ \\
\hline$K_{c} / Y_{c}$ & 2.53 & 2.59 & 2.66 & 2.79 \\
\hline$w$ & 0.78 & 0.80 & 0.81 & 0.83 \\
\hline$r$ & $8.29 \%$ & $7.86 \%$ & $7.53 \%$ & $6.92 \%$ \\
\hline$\%$ of applications & $4.64 \%$ & $3.72 \%$ & $3.92 \%$ & $1.97 \%$ \\
\hline Rent seeking costs / Y & $10.04 \%$ & $7.46 \%$ & $7.11 \%$ & $3.54 \%$ \\
\hline
\end{tabular}


and aligning the public sector pension to the private one. ${ }^{41}$ Welfare effects are measured by the permanent increase/decrease in consumption such that the utility of each individual in the baseline economy is similar to the economy with the government reform - pension reform and reduction in the public wage premium. Welfare is measured by the ex-ante expected (with respect to idiosyncratic shocks) lifetime utility of a newborn in a stationary equilibrium. Given that all newborns start with zero assets, welfare effects are the consumption-equivalent such that the expected value function for a given individual at age 25 is the same in the baseline model and in the counterfactual economy. As can be seen in Figure 7, all individuals would in the longrun be better-off with the aforementioned policy change. This policy reform increases the wage rate and productivity with positive effects on welfare. More importantly, the model predicts that individuals with low working and entrepreneurial abilities would be the ones who benefit the most, with their welfare increasing nearly $7.5 \%$ in consumption-equivalent to the baseline. The intuition behind this result is that these individuals benefit much less from the generosity of the public sector compensation as application decisions are correlated with abilities and income. In addition, their welfare would increase by the rise in the marginal productivity of labor.

The welfare measure report in Figure 7 compares the welfare of individuals in two different economies at the age 25 before they make their economic decisions. It shows that in the long-run all individuals at the age 25 would be better off in an economy with a lower public earnings premium. Although this welfare figure is informative, a complete analysis of the welfare would require us to compute the transition dynamics after the reform and the welfare of all individuals during transition. Certainly the reform above would generate some welfare losses during transition given that individuals who are civil servants before the reform would have a major reduction on their earnings. Such individuals would have a vested interest in an overpaid public sector and could erect barriers to block reforms which would decrease the public earnings premium. A strategy to mitigate some of these welfare losses would be to implement a gradual reform, such that during transition two systems in the public sector would co-exist. An old system of earnings for existing civil servants and an alternative one for new public employees, which would be less generous. It is not clear if such reforms could also be implemented but some countries have succeed to

\footnotetext{
${ }^{41}$ We only show the case in which we adjust $\bar{q}$ to keep the share of civil servants unchanged. Results when we adjust $\theta$ are similar and for the sake of space we do not present them here.
} 


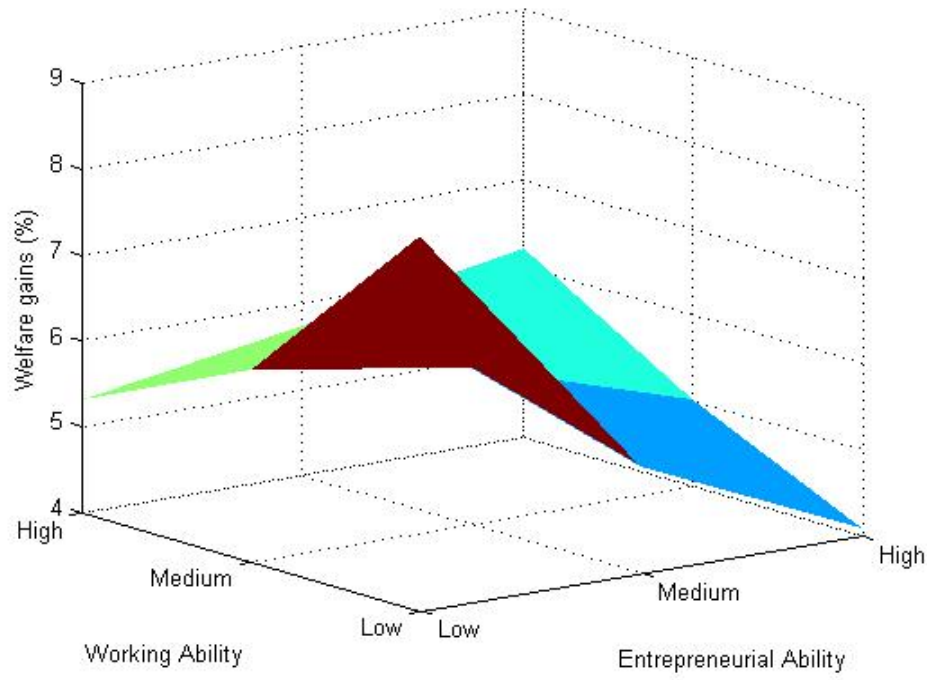

Figure 7: Welfare. The $\mathrm{z}$ axis measures the percentage change in welfare when we change the wage premium to $19 \%$ and the social security parameters, adjusting $\bar{q}$ to keep the share of civil servants unchanged.

increase retirement age and to change the pension system for new workers.

Partial equilibrium. We have shown that government reforms which reduce earnings and compensation premium in the public sector can have sizeable impacts on productivity, output and long-run welfare. It is also important to understand the main channels which explain the overall effect on the economy of such reforms. One way to accomplish this is to consider a partial equilibrium analysis, by fixing prices at their benchmark level. As we observed in the lower half of Table 4, the capital to output ratio increases by more than $10 \%$ when we change the wage premium and the social security parameters in the public sector. This sizeable impact on capital stock leads to large movements in the price of factors of production which can have potentially important effects on the economy. We now investigate how important these effects are.

Now we repeat the same experiment carried out in Table 4 but we keep the price of factors of production at their baseline level. ${ }^{42}$ Results are presented in Table 5 . When prices are held at their initial level then it is the supply of inputs which solely

\footnotetext{
4 .

${ }^{42}$ It should be highlighted that we use the same adjusted $\theta$ and $\bar{q}$ found in the experiments in Table
} 
determines their use in production. ${ }^{43}$ Changing the wage premium and the social security parameters in the public sector lead to an increase in asset accumulation, which would be stronger without prices adjustment. For instance, for the case where we adjust $\bar{q}$, the capital-output ratio increases from 2.53 to 3.46 (as opposed to 2.79 with price adjustment). Table 5 shows that the effects on the entrepreneurial sector are large with fixed prices. Notice that while total output increases by $26.4 \%$, output in the entrepreneurial sector increases nearly $35 \%$ (as oppose to $-17.16 \%$ with price adjustments) when $\bar{q}$ is adjusted. Given that $\frac{Y_{e}}{Y}=0.154$ in the benchmark case, it is straightforward to show that nearly $21 \%$ of the growth in total output is now explained by the entrepreneurial sector (as oppose to $-2.6 \%$ with price adjustments). This sizeable increase in $Y_{e}$ is, in turn, largely explained by the rise in the share of entrepreneurs (not shown in this table), which goes from $4.69 \%$ in the benchmark case to $6.9 \%$ (as oppose to $3.8 \%$ with price adjustments).

Interestingly, this increase in the share of entrepreneurs takes place mostly to the detriment of the share of civil servants, which falls to $7.54 \%$ thereby reducing the supply of public goods, $G$, in nearly $14 \%$. Our interpretation of this result is that the increase in capital accumulation raises the potential for many agents with high entrepreneurial ability to self-finance themselves and thus become entrepreneurs instead of working to the government. In addition, since the wage rate is kept constant and, as a consequence, labor is cheaper under partial equilibrium than when prices adjust, then this also contributes to the expansion of the entrepreneurial sector. This partial equilibrium analysis shows the importance of the entrepreneurial sector in reforms which decrease earnings premium in the public sector.

\subsubsection{The effects of reducing stability}

In Table 6 we reduce the employment stability in the public sector by decreasing the persistence parameter, $\rho_{g}$, from the idiosyncratic shock in the public sector from 0.98 to 0.95 . We keep all other parameters at their baseline level except either the search $\operatorname{cost} \theta$ or the probability of getting a public sector job offer $\bar{q}{ }^{44}$ We adjust either $\theta$ (Experiment $2 \mathrm{~A}$ ) or $\bar{q}$ (Experiment $2 \mathrm{~B}$ ) in order to keep the share of public employees constant. One implication of this change is that public sector jobs become more

\footnotetext{
${ }^{43}$ The presence of a large corporate sector with a constant returns to scale technology implies that the demand for labor and capital are horizontal.

${ }^{44}$ This changes the grid points and the transition probability matrix for $s_{g}$.
} 
Table 5: Changing all factors: partial equilibrium. The second column displays results when we only change the wage premium to $19 \%$; The third column shows results when we align the parameters of the public and private social security systems; In the fourth column, we show results when we change all factors at the same time. In all exercises, we keep the prices at their benchmark levels. The first column shows the benchmark case for convenience.

\begin{tabular}{|c|c|c|c|c|}
\hline \multicolumn{5}{|c|}{ Adjusting $\theta$} \\
\hline Variable & Baseline & Wage premium & Social Security & All \\
\hline$Y=Y_{c}+Y_{e}$ & 100 & 108.7 & 114.6 & 117.1 \\
\hline$Y_{e} / Y$ & $15.4 \%$ & $18.4 \%$ & $18.9 \%$ & 20.4 \\
\hline$K$ & 100 & 113.2 & 136.7 & 141.2 \\
\hline$N_{p}$ & 100 & 105.7 & 105.3 & 104.4 \\
\hline$\%$ of civil servants & $10.03 \%$ & $10.49 \%$ & $8.55 \%$ & $10.08 \%$ \\
\hline$G / Y$ & $17.4 \%$ & $15.9 \%$ & $13.61 \%$ & $14.23 \%$ \\
\hline G & 100 & 99.62 & 89.6 & 94.8 \\
\hline$\tau_{c}$ & $32.3 \%$ & $28.5 \%$ & $20.43 \%$ & $18.87 \%$ \\
\hline$K_{c} / Y_{c}$ & 2.53 & 2.66 & 3.10 & 3.20 \\
\hline$w$ & 0.78 & 0.78 & 0.78 & 0.78 \\
\hline$r$ & $8.29 \%$ & $8.29 \%$ & $8.29 \%$ & $8.29 \%$ \\
\hline$\%$ of applications & $4.64 \%$ & $4.94 \%$ & $3.06 \%$ & $3.74 \%$ \\
\hline Rent seeking costs / Y & $10.04 \%$ & $8.08 \%$ & $6.02 \%$ & $5.26 \%$ \\
\hline \multicolumn{5}{|c|}{ Adjusting $\bar{q}$} \\
\hline Variable & Baseline & Wage premium & Social Security & All \\
\hline$Y=Y_{c}+Y_{e}$ & 100 & 113.9 & 113.7 & 126.4 \\
\hline$Y_{e} / Y$ & $15.4 \%$ & $20.5 \%$ & $18.5 \%$ & $16.82 \%$ \\
\hline K & 100 & 126.2 & 133.6 & 168.1 \\
\hline$N_{p}$ & 100 & 106.7 & 105.4 & 111.2 \\
\hline$\%$ of civil servants & $10.03 \%$ & $9.59 \%$ & $8.61 \%$ & $7.54 \%$ \\
\hline$G / Y$ & $17.4 \%$ & $15.12 \%$ & $13.78 \%$ & $11.80 \%$ \\
\hline G & 100 & 98.93 & 90.01 & $85.7 \%$ \\
\hline$\tau_{c}$ & $32.3 \%$ & $28.48 \%$ & $21.79 \%$ & $19.97 \%$ \\
\hline$K_{c} / Y_{c}$ & 2.53 & 2.88 & 3.04 & 3.46 \\
\hline$w$ & 0.78 & 0.78 & 0.78 & 0.78 \\
\hline$r$ & $8.29 \%$ & $8.29 \%$ & $8.29 \%$ & $8.29 \%$ \\
\hline$\%$ of applications & $4.64 \%$ & $3.60 \%$ & $3.47 \%$ & $1.64 \%$ \\
\hline Rent seeking costs / Y & $10.04 \%$ & $6.84 \%$ & $6.60 \%$ & $2.81 \%$ \\
\hline
\end{tabular}


Table 6: Decreasing job stability. We decrease the persistence parameter $\rho_{g}$ from 0.98 to 0.95 ; In Experiment $2 A$, we also adjust $\theta$ to keep the share of civil servants unchanged, while in Experiment $2 B$ we adjust $\bar{q}$.

\begin{tabular}{lccc}
\hline \hline Variable & Baseline & Experiment 2A & Experiment 2B \\
\hline$Y=Y_{c}+Y_{e}$ & 100 & 99.44 & 98.18 \\
$Y_{e} / Y$ & $15.4 \%$ & $16.0 \%$ & $17.1 \%$ \\
$K$ & 100 & 99.3 & 96.2 \\
$N_{p}$ & 100 & 99.7 & 98.3 \\
$\%$ of civil servants & $10.03 \%$ & $10.02 \%$ & $10.06 \%$ \\
$G / Y$ & $17.4 \%$ & $17.6 \%$ & $17.97 \%$ \\
$G$ & 100 & 100.7 & 101.4 \\
$\tau_{c}$ & $32.3 \%$ & $32.2 \%$ & $31.8 \%$ \\
$K_{c} / Y_{c}$ & 2.53 & 2.52 & 2.49 \\
$w$ & 0.78 & 0.78 & 0.78 \\
$r$ & $8.29 \%$ & $8.31 \%$ & $8.45 \%$ \\
$\%$ of applications & $4.64 \%$ & $4.58 \%$ & $5.21 \%$ \\
Rent seeking costs $/ \mathrm{Y}$ & $10.04 \%$ & $10.82 \%$ & $11.48 \%$ \\
\hline
\end{tabular}

volatile and more attractive for individuals with high productivity shocks. This is because the grid points for $s_{g}$ becomes closer to its private sector counterpart. There is an increase in applications since the decision to search for a public sector job is correlated with income and assets. Consequently, more resources are spent on searching for a public job and less on capital accumulation. Labor units decrease in the private sector. The effects on prices and aggregate output are small. In Experiment 2A output reduces by 0.54 percent and in Experiment 2B it reduces by 1.92 percent. Notice that in both cases the supply of public infrastructure increases. This is due to the reallocation of labor since there are more high productive workers applying for a public job.

\section{Concluding remarks}

Differences in earnings and labor legislations between public and private workers might have an impact on the occupational decision of agents. The public sector might attract high productive and risk averse agents looking for a more stable and higher paid job, creating a public sector job queue and crowding out private sector employment and entrepreneurship. This can be particularly important in countries with an overpaid and large public sector facing pressure for fiscal consolidation. We con- 
struct a development economy with endogenous occupational choice, heterogeneous agents and imperfect enforcement which is able to assess the role of public-private earnings premium on aggregate output and productivity and can be applied to different environments and countries. We apply this to Brazil, which is a country with a high public wage premium and an unequal pension system for existing workers. We show that public sector reforms which would decrease the public sector earnings premium could have important long-run aggregate effects on factor prices, productivity and output. For instance, a reform which would decrease the public-private wage premium from $25 \%$ to $13 \%$ could increase aggregate output by $6.5 \%$ to $16 \%$ in the long-run without any significant effect on public infrastructure. Similarly, a reform which would align the public and private social security regimes would also have sizeable long-run effects on efficiency - an increase in roughly $8 \%$ in aggregate output. We show that in the long-run all individuals at age 25 (initial period of life in the model) would be better off in an economy with a lower public earnings premium. Nevertheless, during transition such reforms could generate important welfare losses for some individuals who would have a vested interest in an overpaid public sector and could erect barriers to block them.

\section{References}

Acemoglu, D., And F. Zilibotti (2001): “Productivity Differences," The Quarterly Journal of Economics, 116(2), 563-606. 5

AmARAL, P., AND E. QUiNTIN (2010): “Limited Enforcement, Financial Intermediation and Economic Development: A Quantitative Assessment," International Economic Review, 51(3), 785-811. 6

Antunes, A., And T. CAVAlCANTI (2007): “Start Up Costs, Limited Enforcement, and the Hidden Economy," European Economic Review, 51(1), 203-224. 6

Antunes, A., T. CAVAlCANTI, And A. Villamil (2008): "The Effect of Financial Repression \& Enforcement on Entrepreneurship and Economic Development," Journal of Monetary Economics, 55(2), 278-298. 6

BARro, R. J. (1990): “Government Spending in a Simple Model of Endogenous Growth," Journal of Political Economy, 98, S103-S125. 10 
Belluzzo, W., F. Anuatti-Neto, and E. T. Pazello (2005): “Distribuição de Salários e o Diferencial Público-Privado no Brasil," Revista Brasileira de Economia, 59(4), 511-533. 8

Beshears, J., J. J. Choi, D. Laibson, And B. C. MAdrian (2011): “Behavioral Economics Perspectives on Public Sector Pension Plans," Journal of Pension Economics and Finance, 10(2), 315-336. 9

Browning, M., L. HAnsen, and J. Heckman (1999): “Micro data and general equilibrium models. In: Taylor, J.B., and Woodford, M. (Eds.)," Handbook of Macroeconomics. 28,29

BuerA, F. J., AND Y. SHIN (2013): "Financial Frictions and the Persistence of History: A Quantitative Exploration," Journal of Political Economy, 121 (2), 221-272. 6

CASelli, F. (2005): "Accounting for Cross-Country Income Di?erences," in Handbook of Economic Growth, ed. by P. Aghion, and S. Durlauf, vol. 1. Elsevier. 5

Caselli, F., And N. Gennaioli (2013): “Dynastic Management," Economic Inquiry, 51(1), 971-996. 6

Clark, A., And F. Postel-Vinay (2009): “Job Security and Job Protection," Oxford Economic Papers, 61(2), 207-239. 9

Cunha, F., P. C. Ferreira, And M. R. DOS SAntos (2012): “The Impact of Social Security Reform on Occupational and Retirement Behavior," Working Paper, University of Pennsylvania. 9

DaVid, J. M., H. A. Hopenhayn, And V. VenKateswaran (2014): “Information, Misallocation and Aggregate Productivity," Mimeo, UCLA. 6

Depalo, D., R. Giordano, and E. Papapetrou (2013): “Public-Private Wage Differentials in Euro Area Countries: Evidence from Quantile Decomposition Analysis," Working Paper 907, Banca D'Italia. 3, 8

Erosa, A., AND A. Hidalgo-Cabrillana (2008): “On Finance as a Theory of TFP, Cross-Industry Productivity Differences, and Economic Rents," International Economic Review, 49(2), 437-473. 6 
FinANCIAL TIMES (2009): "Public servants give techies the push in India's marriage market," Financial Times, February 25th. 2

(2014): “Brazil's Love of ‘Pork' Explains Obesity Levels," Financial Times, May 7th. 4

Garcia-Milà, T., T. J. McGuire, and R. H. Porter (1996): “The Effect of Public Capital in State-Level Production Functions Reconsidered," Review of Economics and Statistics, 78(1), 177-180. 53

GLOMM, G., J. JUNG, AND C. TRAN (2009): “Macroeconomic Implications of Early Retirement in the Public Sector: The Case of Brazil," Journal of Economic Dynamics and Control, 33(4), 777-797. 6

GolliN, D. (2002): “Getting Income Shares Right," Journal of Political Economy, 110(2), 458-474. 27, 29

Gomes, P. (2014): “Optimal Public Sector Wages,” Forthcoming Economic Journal. 6

Guner, N., G. Ventura, And X. Yi (2008): “Macroeconomic Implications of Size Dependent Policies," Review of Economic Dynamics, 11(4), 721-744. 6

He, H., F. HuAnG, Z. LiU, And D. ZHU (2014): "Breaking the "Iron Rice Bowl" and Precautionary Swings: Evidence from Chinese State-Owned Enterprises Reform," Working Paper Series 2014-4, Federal Reserve Bank of San Francisco. 9, 28

Heston, A., R. Summers, And B. Aten (2012): "Penn World Table Version 7.1," Center for International Comparisons at the University of Pennsylvania (CICUP). 26

Holtz-EAKIN, D. (1994): "Public-Sector Capital and the Productivity Puzzle," Review of Economics and Statistics, 76(1), 12-21. 51

Hörner, J., L. R. NGai, And C. Olivetti (2007): “Public Eenterprises and Labor Market Performance," International Economic Review, 48(2), 363-384. 6

HsieH, C.-T., E. HuRst, C. I. Jones, AND P. J. KlenOW (2013): “The Allocation of Talent and U.S. Economic Growth," Mimeo, Stanford University. 6 
HsieH, C.-T., AND P. KLENOW (2009): "Misallocation and Manufacturing TFP in China and India," The Quarterly Journal of Economics, 124(4), 1403-1448. 5

(2010): “Development Accounting," American Economic Journal: Macroeconomics, 2(1), 207-223. 5

Huggett, M., G. Ventura, And A. YARON (2006): “Human Capital and earnings distribution dynamics," Journal of Monetary Economics, 53, 265-290. 28

Hulten, C. (1996): "Infrastructure capital and economic growth: how well you use it may be more important then how much you have," NBER Working Paper 5847. $27,29,51$

Jaimovich, E., And J. P. Rud (2014): “Excessive Public Employment and RentSeeking Traps," Journal of Development Economics, 106, 144-155. 6

KAPLAN, G. (2012): "Inequality and the Lifecycle," Quantitative Economics, 3, 471525. 28

LUCAS, JR, R. E. (1978): “On the Size Distribution of Business Firms," Bell Journal of Economics, 9(2), 508-523. 4, 10

(1990): "Supply-side economics: an analytical review," Oxford Economic Papers, 42(2), 293-316. 5

Mehra, R., And E. C. Prescott (1985): “The Equity Premium: A puzzle," Journal of Monetary Economics, 15, 145-162. 26, 29

Melitz, M. J. (2003): “The Impact of Trade on Intra-Industry Reallocations and Aggregate Industry Productivity," Econometrica, 71(6), 1695-1725. 6

Meltzer, A. H., And S. F. Richard (1981): "A Rational Theory of the Size of Government," Journal of Political Economy, 89(5), 914-927. 8

Midrigan, V., AND D. Y. XU (2013): "Finance and Misallocation: Evidence from Plant-Level Data," Forthcoming American Economic Review. 6

Mortensen, D., ANd C. Pissarides (1994): "Job Creation and Job Destruction in the Theory of Unemployment," Review of Economic Studies, 61, 397-415. 4, 22 
OECD (2011): Government at a Glance 2011. OECD: Paris. 2, 4, 9, 28

PaEs, N. L., AND M. N. S. Bugarin (2006): "Parâmetros Tributários da Economia Brasileira," Estudos Econômicos, 36(4), 699-720. 28, 29

Parente, S. L., And E. C. Prescott (1994): “Barriers to technology adoption and development," Journal of Political Economy, 102(2), 298-321. 5

(2000): Barriers to riches. MIT Press, Cambridge, Massachusetts. 27

Postel-Vinay, F., And H. Turon (2007): “The Public Pay Gap in Britain: Small Differences That (Don't?) Matter," The Economic Journal, 117(523), 1460U11503. 8

QUADRINI, V. (2000): "Entrepreneurship, Saving, and Social Mobility," The Review of Economic Dynamics, 3(1), 1-40. 17

Quadrini, V., AND A. TRigari (2007): "Public Employment and the Business Cycle," The Scandinavian Journal of Economics, 109(4), 723-742. 6

Queisser, M., E. Whitehouse, and P. Whiteford (2008): “The PublicĐPrivate Pension Mix in OECD Countries," Industrial Relations Journal, 38(6), 542Đ568. 9

Reis, A. C. D., And E. Zilberman (2014): “The Insurance Role of Public Employment," Mimeo, PUC-RJ. 7, 28

Restuccia, D., And R. Rogerson (2008): "Policy Distortions and Aggregate Productivity with Heterogeneous Establishments," Review of Economic Dynamics, 11(4), 707-720. 6

(2013): “Misallocation and Productivity," Review of Economic Dynamics, 16(1), $1-10.6$

RODRIK, D. (1998): “Why Do More Open Economies Have Bigger Governments?," Journal of Political Economy, 106(5), 997-1032. 8

Rosen, S. (1996): "Public Employment and the Welfare State in Sweden," Journal of Political Economy, 34(2), 729-740. 8

Song, Z., K. Storesletten, And F. Zilibotti (2011): “Growing Like China," American Economic Review, 101(1), 202-241. 6 
TAfner, P. (2011): “Previdência no Brasil: Um (Modesto) Passo Adiante nas Reformas," Working Paper, Ministério da Previdência Social do Brasil. 9

TANSel, A. (2005): "Public-Private Employment Choice, Wage Differentials, and Gender in Turkey," Economic Development and Cultural Change, 53(2), 453-477. 8

TAuCHen, G. (1986): "Finite-State Markov Chain Approximations to Univariate and Vector Autoregressions," Economics Letters, 20, 177-181. 27

THE ECONOMIST (2014): "Disillusioned office workers: China's losers," The Economist, April 19th. 2

The New York Times (2013): “Brazil, Where a Judge Made US\$361,500 in a Month, Fumes Over Pay," The New York Times, February 10th. 2

WALLENIUS, J. (2011): “Human capital accumulation and the intertemporal elasticity of substitution of labor: How large is the bias?," Review of Economic Dynamics, 14, 577-591. 28

WYNNE, J. (2005): "Wealth as a Determinant of Comparative Advantage," American Economic Review, 95(1), 226-254. 17 
Table 7: Summary statistics. Source: 2008 PNAD. Income per hour is constructed by dividing individuals' monthly income in their main job by the numbers of hour worked in this job. We considered only individuals who have worked at least 20 hours per week. The data below corresponds to 25-65 years old individuals.

\begin{tabular}{|c|c|c|c|c|c|c|}
\hline & $\begin{array}{l}\text { Fraction in the } \\
\text { population } \\
\text { (25-65 years) }\end{array}$ & $\begin{array}{c}\text { Average } \\
\text { income per } \\
\text { hour }(\mathrm{R} \$)\end{array}$ & $\begin{array}{l}\text { Median- } \\
\text { mean } \\
\text { ratio }\end{array}$ & $\begin{array}{l}\text { Std dev. } \\
\text { of income } \\
\text { per hour }\end{array}$ & $\begin{array}{l}\text { Gini of } \\
\text { income } \\
\text { per hour }\end{array}$ & $\begin{array}{c}\text { Average } \\
\text { tenure on } \\
\text { the job }\end{array}$ \\
\hline All individuals & $100 \%$ & 6.15 & 0.57 & 9.55 & 0.51 & 7.83 \\
\hline Civil servants & $10 \%$ & 11.71 & 0.63 & 13.71 & 0.48 & 13.37 \\
\hline Private workers & $85.5 \%$ & 5.46 & 0.64 & 7.25 & 0.46 & 6.69 \\
\hline \multirow[t]{2}{*}{ Entrepreneurs } & $4.5 \%$ & 14.94 & 0.59 & 23.08 & 0.53 & 10.87 \\
\hline & $\begin{array}{c}\text { Average } \\
\text { income per } \\
\text { hour }(\mathrm{R} \$) \\
\text { at age } 25\end{array}$ & $\begin{array}{l}\text { Std dev. } \\
\text { of income } \\
\text { per hour } \\
\text { at age } 25\end{array}$ & & & & \\
\hline $\begin{array}{l}\text { workers and } \\
\text { civil servants }\end{array}$ & 4.27 & 3.88 & & & & \\
\hline Entrepreneurs & 11.85 & 13.30 & & & & \\
\hline
\end{tabular}

\section{A PNAD Data and Estimation}

This appendix presents statistics and regression results for the Brazilian economy using the 2008 Brazilian National Household Survey PNAD (Pesquisa Nacional por Amostra de Domicílios). Table 7 contains summary statistics for individuals who have worked at least 20 hours per week and are 25-65 years old. We classify the occupation of individuals by their main occupation. Table 8 presents results for 8 Mincerian regressions in which the dependent variable is the logarithm of income per hour for different sample of individuals and controls. 
Table 8: Log of income per hour. Source: 2008 PNAD.

\begin{tabular}{|c|c|c|c|c|c|c|c|c|}
\hline & $\begin{array}{c}\text { (1) } \\
\text { All } \\
\text { indiv. } \\
\text { (>=16 yrs) }\end{array}$ & $\begin{array}{c}(2) \\
\text { All } \\
\text { indiv. } \\
\text { (25-65 yrs) }\end{array}$ & $\begin{array}{c}(3) \\
\text { Workers } \\
\text { and civil } \\
\text { servants } \\
\text { (25-65 yrs) } \\
\end{array}$ & $\begin{array}{c}(4) \\
\text { Workers } \\
\text { and civil } \\
\text { servants } \\
(25-65 \text { yrs) } \\
\end{array}$ & $\begin{array}{c}(5) \\
\text { Workers } \\
\text { and civil } \\
\text { servants } \\
(25-65 \text { yrs) } \\
\end{array}$ & $\begin{array}{c}\text { (6) } \\
\text { Only } \\
\text { workers } \\
\text { (25-65 yrs) } \\
\end{array}$ & $\begin{array}{c}(7) \\
\text { Only } \\
\text { civil } \\
\text { servants } \\
\text { (25-65 yrs) } \\
\end{array}$ & $\begin{array}{l}\text { Entrepr. } \\
\text { (25-65 yrs) }\end{array}$ \\
\hline Constant & $\begin{array}{c}-0.4357^{* *} \\
(-30.73)\end{array}$ & $\begin{array}{c}-0.2935^{* *} \\
(-8.98)\end{array}$ & $\begin{array}{c}-0.1947^{* *} \\
(-5.57)\end{array}$ & $\begin{array}{c}-0.0901^{* *} \\
(-2.66)\end{array}$ & $\begin{array}{c}0.2036 \\
(5.15)\end{array}$ & $\begin{array}{c}-0.2030^{* *} \\
(-5.51)\end{array}$ & $\begin{array}{c}-0.1379 \\
(-1.20)\end{array}$ & $\begin{array}{l}0.7138 \\
(3.34)\end{array}$ \\
\hline $\begin{array}{l}\text { Middle } \\
\text { school }\end{array}$ & $\begin{array}{c}0.2592^{* *} \\
(49.15)\end{array}$ & $\begin{array}{c}0.26^{* *} \\
(45.30)\end{array}$ & $\begin{array}{c}0.1934^{* *} \\
(28.18)\end{array}$ & $\begin{array}{c}0.2074^{* *} \\
(30.52)\end{array}$ & $\begin{array}{c}0.1901^{* *} \\
(27.81)\end{array}$ & $\begin{array}{c}0.1935^{* *} \\
(27.53)\end{array}$ & $\begin{array}{c}0.1278^{* *} \\
(4.14)\end{array}$ & $\begin{array}{c}0.2312^{* *} \\
(4.95)\end{array}$ \\
\hline $\begin{array}{l}\text { High } \\
\text { School }\end{array}$ & $\begin{array}{l}0.5798^{* *} \\
(114.55)\end{array}$ & $\begin{array}{c}0.585^{* *} \\
(105.97)\end{array}$ & $\begin{array}{c}0.4773^{* *} \\
(73.25)\end{array}$ & $\begin{array}{c}0.5195^{* *} \\
(79.83)\end{array}$ & $\begin{array}{c}0.4691^{* *} \\
(70.67)\end{array}$ & $\begin{array}{c}0.4617^{* * *} \\
(68.89)\end{array}$ & $\begin{array}{c}0.6344^{* *} \\
(22.88)\end{array}$ & $\begin{array}{c}0.5888^{* *} \\
(13.81)\end{array}$ \\
\hline College & $\begin{array}{l}1.3739^{* *} \\
(201.30)\end{array}$ & $\begin{array}{l}1.4247^{* *} \\
(187.52)\end{array}$ & $\begin{array}{l}1.2812^{* *} \\
(152.72)\end{array}$ & $\begin{array}{l}1.3476^{* *} \\
(160.91)\end{array}$ & $\begin{array}{l}1.2701^{* *} \\
(145.92)\end{array}$ & $\begin{array}{l}1.2841^{* *} \\
(140.10)\end{array}$ & $\begin{array}{c}1.3616^{* *} \\
(49.03)\end{array}$ & $\begin{array}{c}1.2241^{* *} \\
(27.38)\end{array}$ \\
\hline Age & $\begin{array}{c}0.0483^{* *} \\
(63.99)\end{array}$ & $\begin{array}{c}0.0427^{* *} \\
(25.97)\end{array}$ & $\begin{array}{c}0.0437^{* *} \\
(24.82)\end{array}$ & $\begin{array}{l}0.042^{* *} \\
(24.58)\end{array}$ & $\begin{array}{c}0.0431^{* *} \\
(24.85)\end{array}$ & $\begin{array}{c}0.0454^{* *} \\
(24.32)\end{array}$ & $\begin{array}{c}0.0437^{* *} \\
(7.92)\end{array}$ & $\begin{array}{c}0.0262^{* *} \\
(2.58)\end{array}$ \\
\hline $\mathrm{Age}^{2}$ & $\begin{array}{c}-0.0004^{* *} \\
(-42.06)\end{array}$ & $\begin{array}{c}-0.0004^{* *} \\
(-18.30)\end{array}$ & $\begin{array}{c}-0.0004^{* *} \\
(-18.11)\end{array}$ & $\begin{array}{c}-0.0004^{* *} \\
(-21.00)\end{array}$ & $\begin{array}{c}-0.0004^{* *} \\
(-18.20)\end{array}$ & $\begin{array}{c}-0.0004^{* *} \\
(-18.40)\end{array}$ & $\begin{array}{c}-0.0003^{* *} \\
(-4.81)\end{array}$ & $\begin{array}{c}-0.0001 \\
(-1.24)\end{array}$ \\
\hline $\begin{array}{l}\text { Civil } \\
\text { servant } \\
\text { Tenure }\end{array}$ & $\begin{array}{c}0.2877^{* *} \\
(44.36)\end{array}$ & $\begin{array}{c}0.2767^{* *} \\
(38.51)\end{array}$ & $\begin{array}{c}0.2978^{* *} \\
(41.25)\end{array}$ & $\begin{array}{c}0.2585^{* *} \\
(36.37) \\
0.0147^{* *} \\
(45.15)\end{array}$ & $\begin{array}{c}0.2378^{* *} \\
(27.60)\end{array}$ & & & \\
\hline Female & & & & $\begin{array}{c}-0.2666^{* *} \\
(-62.53)\end{array}$ & & & & \\
\hline Occupation & $\mathrm{NO}$ & $\mathrm{NO}$ & $\mathrm{NO}$ & $\mathrm{NO}$ & YES & $\mathrm{NO}$ & $\mathrm{NO}$ & $\mathrm{NO}$ \\
\hline $\begin{array}{l}\text { N. of } \\
\text { Observ. }\end{array}$ & 153,093 & 116,477 & 91,264 & 91,264 & 91,264 & 79,145 & 12,119 & 5,931 \\
\hline $\begin{array}{l}\text { Adjusted } \\
R^{2}\end{array}$ & 0.3649 & 0.3533 & 0.3543 & 0.3996 & 0.3771 & 0.2871 & 0.2977 & 0.1898 \\
\hline $\begin{array}{l}\text { Residual } \\
\text { variance }\end{array}$ & 0.4169 & 0.418 & 0.4188 & 0.3964 & 0.4622 & 0.4279 & 0.4290 & 0.4336 \\
\hline
\end{tabular}

$\overline{\text { All specifications include a constant, not reported. T-Statistics are presented in parentheses, using }}$ heterosk.-consistent standard errors. * indicates significant at the 90 percent confidence level and ${ }^{* *} \mathrm{a}$ 95 percent confidence level. 


\section{A.0.4 Robustness exercises - Online appendix (Not for publication)}

In this subsection, we investigate how our main results are affected by changes in the value of some parameters. In particular, we carry out the same set of counterfactual exercises we did in the last column of Table 4, but considering first $\phi=0.5$ (Table 9a), and second $\chi=0.05$ (Table $9 \mathrm{~b}$ ). ${ }^{45}$ A large $\phi$ implies that there is more leverage in the noncorporate sector and entrepreneurs are less credit constrained. Consequently, there is less misallocation due to financial constraints. A smaller $\chi$ results in a lower effect of public infrastructure on output in the private sector. We adjust either the search $\operatorname{cost} \theta$ or the probability threshold $\bar{q}$ to keep the share of public employment constant.

Notice that the effects of reducing the wage premium from $25 \%$ to $19 \%$ and aligning the two pension systems on aggregate output are roughly the same when $\phi=0.50$ instead of $\phi=0.40$. In the case we adjust $\theta$ output increases by $12.3 \%$ instead of $13 \%$ and when we adjust $\bar{q}$, then aggregate output increases by $19.9 \%$ instead of $19.4 \%$. There is not much difference in the impact of this reform on the other variables such factor prices and aggregate capital stocks. Therefore, the aggregate impacts of such a public sector reform on output and other macroeconomic variables do not seem to be driven by the value we have calibrated the enforcement parameter $\phi$.

When we decrease the value of $\chi$ from 0.10 to 0.05 results are, however, considerably different. The same reform which would decrease the public sector earnings premium would increase aggregate output by $20 \%$ when the search cost, $\theta$, is adjusted, and by $27 \%$ when the threshold probability $\bar{q}$ of getting a public sector job is adjusted. Those numbers are considerable larger than those presented in last column of Table 4. With a smaller $\chi$ the marginal contribution to society of a public sector worker is smaller which implies that given the observed public-private earnings differential in Brazil there is potentially more misallocation of resources when $\chi$ is equal to 0.05 than when it is 0.10 . Consequently, this reform which would decrease the public sector earnings premium in Brazil would have a stronger aggregate effect on productivity and factor prices. Clearly, our results depend on the value of $\chi$. We have used the point estimate provided by Hulten (1996). Holtz-Eakin (1994) shows no

\footnotetext{
${ }^{45}$ We do not recalibrate model parameters to match statistics described in Table 1 . This explains why in the benchmark case of Table 9 some statistics are different from those reported in the baseline model of Tables 3, 4 and 6. For instance, the share of entrepreneurial production in total output is larger in an economy with a larger $\phi$. We focus on the impact of the reform relative to each benchmark case.
} 
Table 9: Sensitivity Analysis. The second column in a) shows the results for the benchmark economy when $\phi=0.50$, while the second column in b) shows the results for the benchmark economy when $\chi=0.05$. In the third column of each table, we change the wage premium to $19 \%$ and align the parameters of the public and private social security systems, adjusting $\theta$ to keep the share of civil servants constant; In the fourth column, we do the same experiment as in the third column, but adjust $\bar{q}$ to keep the share of civil servants constant.

\begin{tabular}{|c|c|c|c|}
\hline \multicolumn{4}{|c|}{ a) $\phi=0.50$} \\
\hline Variable & Benchmark & Adjusting $\theta$ & Adjusting $\bar{q}$ \\
\hline$Y=Y_{c}+Y_{e}$ & 100 & 112.3 & 119.9 \\
\hline$Y_{e} / Y$ & $27.5 \%$ & $19.3 \%$ & $15.1 \%$ \\
\hline$K$ & 100 & 123.4 & 137.9 \\
\hline$N_{p}$ & 100 & 110.0 & 115.0 \\
\hline$\%$ of civil servants & $9.13 \%$ & $9.19 \%$ & $9.03 \%$ \\
\hline$G / Y$ & $16.8 \%$ & $14.7 \%$ & $14.06 \%$ \\
\hline G & 100 & 95.52 & 101.2 \\
\hline$\tau_{c}$ & $30.6 \%$ & $20.12 \%$ & $22.43 \%$ \\
\hline$K_{c} / Y_{c}$ & 2.58 & 2.80 & 2.91 \\
\hline$w$ & 0.80 & 0.82 & 0.85 \\
\hline$r$ & $7.86 \%$ & $6.81 \%$ & $6.38 \%$ \\
\hline$\%$ of applications & $4.47 \%$ & $3.61 \%$ & $1.71 \%$ \\
\hline \multicolumn{4}{|c|}{ b) $\chi=0.05$} \\
\hline Variable & Benchmark & Adjusting $\theta$ & Adjusting $\bar{q}$ \\
\hline$Y=Y_{c}+Y_{e}$ & 100 & 120.1 & 127.0 \\
\hline$Y_{e} / Y$ & $15.0 \%$ & $8.2 \%$ & $5.99 \%$ \\
\hline$K$ & 100 & 132.3 & 145.3 \\
\hline$N_{p}$ & 100 & 115.5 & 119.8 \\
\hline$\%$ of civil servants & $14.22 \%$ & $13.98 \%$ & $14.07 \%$ \\
\hline$G / Y$ & $20.1 \%$ & $15.88 \%$ & $15.70 \%$ \\
\hline G & 100 & 94.2 & 99.3 \\
\hline$\tau_{c}$ & $41.2 \%$ & $17.3 \%$ & $19.16 \%$ \\
\hline$K_{c} / Y_{c}$ & 2.51 & 2.74 & 2.83 \\
\hline$w$ & 0.91 & 0.95 & 0.98 \\
\hline$r$ & $8.37 \%$ & $7.13 \%$ & $6.70 \%$ \\
\hline$\%$ of applications & $6.13 \%$ & $4.91 \%$ & $2.64 \%$ \\
\hline
\end{tabular}


quantitatively spillover effects of public capital on private sector productivity in the United States. Similar results are found in Garcia-Milà, McGuire, and Porter (1996). 